\title{
Nurhachius luei, a new istiodactylid pterosaur (Pterosauria, Pterodactyloidea) from the Early Cretaceous Jiufotang Formation of Chaoyang City, Liaoning Province (China) and comments on the Istiodactylidae
}

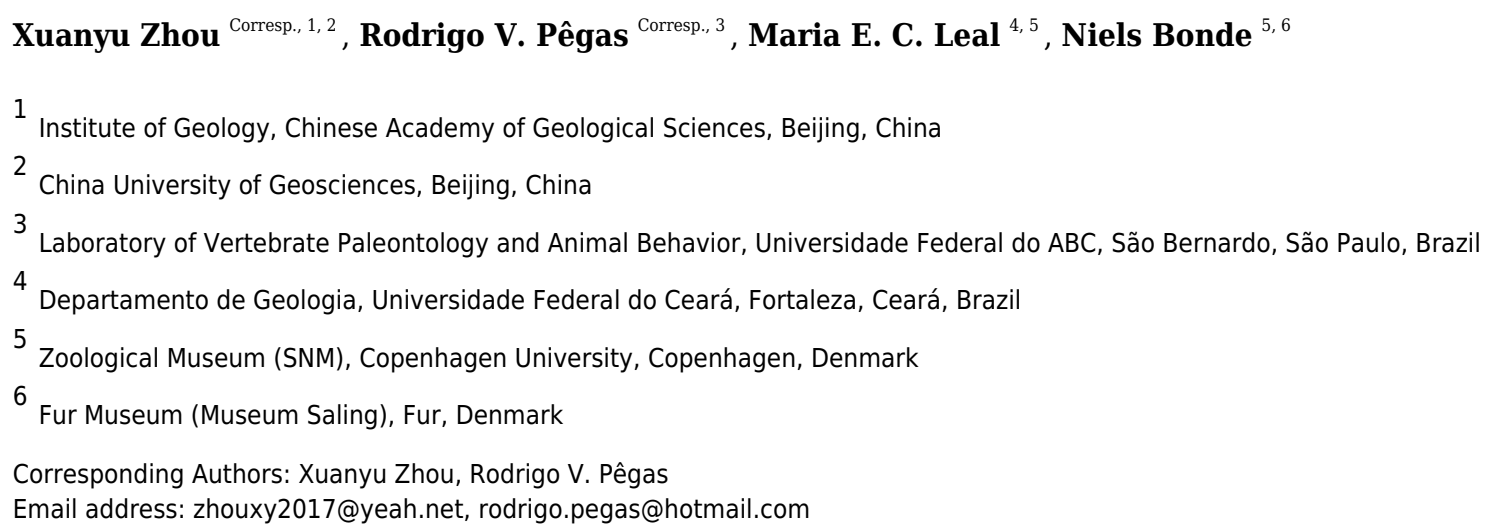

A new istiodactylid pterosaur, Nurhachius luei sp. nov., is here reported based on a complete skull with mandible and some cervical vertebrae from the lower part of the Jiufotang Formation of western Liaoning (China). This is the second species of Nurhachius, the type-species being $N$. ignaciobritoi from the upper part of the Jiufotang Formation. A revised diagnosis of the genus Nurhachius is provided, being this taxon characterized by the presence of a slight dorsal deflection of the palatal anterior tip, which is homoplastic with the Anhangueria and Cimoliopterus. Nurhachius luei sp. nov. shows an unusual pattern of tooth replacement, with respect to other pterodactyloid species. The relationships within the Istiodactylidae and with their closest taxa are investigated through a phylogenetic analysis by parsimony. 
1 Nurhachius luei, a new istiodactylid pterosaur

2 (Pterosauria, Pterodactyloidea) from the Early

3 Cretaceous Jiufotang Formation of Chaoyang City,

4 Liaoning Province (China); and comments on the

5 Istiodactylidae

6 Xuanyu Zhou ${ }^{1,2}$, Rodrigo Vargas Pêgas ${ }^{3}$, Maria Eduarda de Castro Leal ${ }^{4,5}$, Niels Bonde ${ }^{5,6}$

8 1. Institute of Geology, Chinese Academy of Geological Sciences, Beijing, China

9 2. China University of Geosciences, Beijing, China

10 3. Laboratory of Vertebrate Paleontology and Animal Behavior, Universidade Federal do ABC,

11 São Bernardo, São Paulo, Brazil

12 4. Departamento de Geologia, Universidade Federal do Ceará, Fortaleza, Ceará, Brazil

13 5. Zoological Museum (SNM), Copenhagen University, Copenhagen, Denmark

14 6. Fur Museum (Museum Saling), Fur, Denmark

Corresponding Author:

Xuanyu Zhou

No.26 Baiwanzhuang Street, Beijing, Beijing, 100037, China

Email address: zhouxy2017@yeah.net

Rodrigo Vargas Pêgas

Alameda da Universidade, s/n - Anchieta, São Bernardo do Campo - SP, 09606-045, Brazil

Email address: rodrigo.pegas@hotmail.com

\section{Abstract}

A new istiodactylid pterosaur, Nurhachius luei sp. nov., is here reported based on a complete skull with mandible and some cervical vertebrae from the lower part of the Jiufotang Formation of western Liaoning (China). This is the second species of Nurhachius, the type-species being $N$. ignaciobritoi from the upper part of the Jiufotang Formation. A revised diagnosis of the genus Nurhachius is provided, being this taxon characterized by the presence of a slight dorsal deflection of the palatal anterior tip, which is homoplastic with the Anhangueria and Cimoliopterus. 
31 Nurhachius luei sp. nov. shows an unusual pattern of tooth replacement, with respect to other

pterodactyloid species. The relationships within the Istiodactylidae and with their closest taxa are investigated through a phylogenetic analysis by parsimony.

\section{Introduction}

Istiodactylid pterosaurs are characterized by rhombic teeth with lancet-shaped crowns, long skulls with short pre-antorbital portions of the rostrum, and nasoantorbital fenestrae representing over 50 percent of the total skull length and height (Howse et al., 2001; Andres \& Ji, 2006; Lü et al., 2013). The group was originally named by Howse et al. (2001) in order to accommodate, then, only Istiodactylus latidens. Later, the Istiodactylidae were phylogenetically defined by Andres et al. (2014) as the least inclusive clade containing Nurhachius and Istiodactylus.

Four pterosaur genera and five species (all represented by a single specimen) have been referred to the Istiodactylidae sensu Andres et al. (2014) in the literature, namely Istiodactylus latidens, I. sinensis, Liaoxipterus brachyognathus, Nurhachius ignaciobritoi and Longchengpterus zhaoi. However, Longchengpterus zhaoi has been considered a junior synonym of $N$. ignaciobritoi by Lü et al. (2008), a view that is followed here (see Discussion). Therefore, $N$. ignaciobritoi is the only Chinese istiodactylid species to be represented by two specimens so far. Haopterus gracilis, Hongshanopterus lacustris and Archaeoistiodactylus linglongtaensis have been reported in literature as taxa that are close to the Istiodactylidae (Wang XL \& Lü, 2001; Wang XL et al., 2008a; Lü \& Fucha, 2010). However, the affinity of Archaeoistiodactylus linglongtaensis has been questioned by Sullivan et al. (2014).

All istiodactylid pterosaurs are from the Early Cretaceous Jiufotang Formation of northeastern China with the exception of Istiodactylus latidens, which is from the Early Cretaceous Vectis Formation of the Isle of Wight, Southern England. Also, the three taxa that are reported as close to istiodactylids come from northeastern China and surrounding areas: Haopterus gracilis is from the Early Cretaceous Yixian Formation, Hongshanopterus lacustris from the Jiufotang Formation, and Archaeoistiodactylus linglongtaensis from the Middle Jurassic Tiaojishan Formation. Apart from the latter, these Chinese pterosaurs belong to the Jehol Biota (see Chang et al., 2003).

By the end of 2016, 23 species of pterosaurs from the Jiufotang Formation have been reported 
60 (Andres \& Ji, 2006; Dong \& Lü, 2005; Dong et al., 2003; Jiang et al.,2016; Rodrigues et al.,

61 2015; Li et al., 2003; Lü \& Ji, 2005; Lü \& Yuan, 2005; Lü et al., 2006, 2007, 2008, 2016a, 2016b; Wang L et al., 2006; Wang XL \& Zhou, 2003a, 2003b; Wang XL et al., 2005, 2008a, 2008b, 2012, 2014).

In this paper, we describe a second species of Nurhachius from the Jiufotang Formation and investigate the phylogenetic relationships of the istiodactylids and purported close taxa.

\section{Geological, paleontological and geochronological information}

The Jiufotang Formation is known worldwide for its paleontological richness and the exquisite preservation of its fossils, which include plants, insects, fishes, mammals, birds, non-avian dinosaurs and pterosaurs (Wang X, 2018; Meng et al., 2011; Wang M and Zhou, 2019; Yao et al., 2019). Fossils occur mainly in the lower part of the formation, known as Boluochi Beds or 
underlying Tuchengzi Formation to $139.5 \pm 1.0 \mathrm{Ma}$. The upper part of the Yixian Formation (the Jingangshan Beds) was dated to 126.5 Ma (Chang et al., 2003). Therefore, the Yixian Formation represents an interval of $\sim 7 \mathrm{Ma}$ from early Barremian to early Aptian and the Jiufotang Formation might represents an interval of over $11 \mathrm{Ma}$ from early Aptian to early Albian.

The Jehol Group has yielded the famous Jehol biota. Four fossil-bearing levels with partly different fossil associations have been distinct within the Yixian Formation and only one (corresponding to the Boluochi Beds) in the Jiufotang Formation (Chang et al. 2003).

Both the holotype of $N$. ignaciobritoi and its referred specimen (the holotype of Longchengpterus zhaoi) come from the upper part of the Jiufotang Formation (see Wu et al., 2018), whereas the new species comes from the Boluochi Beds (lower part of the Jiufotang Formation).

\section{Material \& Methods}

The holotype and only specimen of the new species consists of a skull with mandible and seven articulated cervical vertebrae. It was previously figured in Lü et al. (2013, figures at pp. 81-82) and reported as an unnamed istiodactylid. The specimen was found near the village of Huanghuatan (Dapingfang town, Chaoyang City, western Liaoning).

For the comparisons we present, the following taxa/specimens were analyzed first-hand (by XZ): Nurhachius ignaciobritoi (both specimens, LPM 00023 and IVPP V-13288), Liaoxipterus brachyognathus holotype (CAR-0018), Hongshanopterus lacustris holotype (IVPP V14582) and Haopterus gracilis holotype (IVPP V11726). Data from other taxa was gathered from the literature.

A phylogenetic analysis was performed based on the data matrix by Holgado et al. (2019) modified with the inclusion of characters by Lü et al. (2008), Witton (2012), Andres et al. (2014), and new characters; and the addition of the following taxa: Archaeoistiodactylus linglongtaensis, Kunpengopterus sinensis, Liaoxipterus brachyognathus and Nurhachius luei sp. nov. (see SI). The analysis was performed by TNT (Goloboff et al., 2008) using the Traditional Search option, 10000 replicates, random seed $=0$ and collapsing trees after search. The character and character states 
116 list and the TNT file with the data matrix are available in the SI.

117 The electronic version of this article in Portable Document Format (PDF) will represent a 118 published work according to the International Commission on Zoological Nomenclature (ICZN), 119 and hence the new names contained in the electronic version are effectively published under that 120 Code from the electronic edition alone. This published work and the nomenclatural acts it contains 121 have been registered in ZooBank, the online registration system for the ICZN. The ZooBank 122 LSIDs (Life Science Identifiers) can be resolved and the associated information viewed through 123 any standard web browser by appending the LSID to the prefix http://zoobank.org/. The LSID for 124 this publication is: urn:lsid:zoobank.org:pub:03EF173E-4AB5-4C74-B80C-A6AAFA65E61C. 125 The online version of this work is archived and available from the following digital repositories: 126 PeerJ, PubMed Central and CLOCKSS.

\section{Results}

\section{Systematic Paleontology}

Pterosauria Kaup, 1834

Pterodactyloidea Plieninger,1901

Istiodactylidae Howse et al., 2001 (sensu Andres et al., 2014)

Nurhachius Wang XL et al., 2005

Type species. Nurhachius ignaciobritoi Wang XL et al., 2005

Synonym. Longchengpterus zhaoi Wang L et al., 2006

Emended Diagnosis. Istiodactylids that share the following features: slight dorsal deflection of the palatal anterior tip; orbit piriform; craniomandibular joint located under the anterior margin of the orbit; dentary symphysis about one third the length of the mandible; dentary symphysis with gradual taper of the lateral margins; triangular, laterally compressed teeth lacking carinae; crowns with both labial and lingual slight concavities; slight constriction between tooth crown and root. 
142

143

144

145

146

147

148

149

150

151

152

153

154

155

156

157

158

159

160

161

162

163

164

165

166

167

168

169

170

Nurhachius luei sp. nov.

ZooBank LSID for species. urn:lsid:zoobank.org:act:6F93DC7F-20A7-4CBC-8A381D6C802A1906.

Etymology. The specific name luei (/ lyi/) honors the late Prof. Junchang Lü, who has made great contributions to the study of Chinese pterosaurs.

Holotype. Skull, mandible and seven cervical vertebrae (BPMC-0204). The specimen is permanently deposited and available for researchers at a public repository, the Beipiao Pterosaur Museum of China, Beipiao, Liaoning Province, China (Fig. 1).

Type Locality and Horizon. Huanghuatan village, Dapingfang town, Chaoyang City, Liaoning Province, China (Fig. 2); lower part of the Jiufotang Formation, Early Cretaceous (Aptian).

Differential diagnosis. The new species is diagnosed based on the following features: quadrate inclined at $150^{\circ}$; medial process of the pterygoid broad and plate-like; dorsal median sulcus of the mandibular symphysis extending up to the first pair of mandibular teeth; dorsally directed odontoid (pseudotooth) of the mandibular symphysis, lacking a foramen on the lateral side and with a blunt occlusal surface; ceratobranchial I of the hyoids accounting for $60 \%$ of mandibular length; mandibular teeth extending distally beyond the symphysis.

\section{Description}

Skull and mandible. The skull is exposed in right lateral view, with some palatal elements that are visible in dorsal view. The mandible is exposed in right dorsolateral view. The skull is $300 \mathrm{~mm}$ long from the squamosal to the premaxillary tip (total skull length), and $74 \mathrm{~mm}$ high at its greatest height, which is at the level of the occiput. The nasoantorbital fenestra is long, corresponding to $45 \%$ of the total skull length (premaxilla to squamosal) and $55 \%$ of the length from the craniomandibular joint to the premaxilla. Anterior to the nasoantorbital fenestra, the long axis of the rostrum is slightly deflected dorsally, as in other istiodactylids (Wang XL et al., 2005; Andres \& Ji, 2006; Lü et al., 2008; Witton, 2012), as well as Ikrandraco avatar and anhanguerians (e.g. Kellner \& Tomida, 2000; Wang XL et al., 2014; 2015; Holgado et al., 2019), but unlike boreopterids (Lü \& Ji, 2005; Lü, 2010; Jiang et al., 2014). There is a strong palatal keel extending 
171 from pre-narial part of the rostrum to the anterior third of the nasoantorbital fenestra. The 172 craniomandibular joint levels with the anterior margin of the orbit, similarly to both specimens of N. ignaciobritoi (see Fig. 3; both specimens, LPM 00023 and IVPP V-13288; see Wang XL et al., 2005; Wang L et al., 2006; Lü et al., 2008), Anhanguera spp. (see Kellner \& Tomida, 2000) and Linlongopterus jennyae (see Rodrigues et al., 2015), but unlike Istiodactylus spp., in which the joint is located anterior to the orbit (see Andres \& Ji, 2006; Witton, 2012), and Ikrandraco avatar (see Wang XL et al., 2015), Hamipterus tianshanensis (see Wang XL et al., 2014) and Ludodactylus sibbicki (Frey et al., 2003), in which the joint is located under the middle of the orbit. The orbit is piriform, with the narrowest part being ventral, and without a suborbital vacuity. This is similar to the condition seen in the referred specimen of $N$. ignaciobritoi and unlike the rounded orbit of Istiodactylus, which has also a suborbital vacuity (see Andres \& Ji, 2006; Lü et al., 2008; Witton, 2012). The infratemporal fenestra is elliptical and much smaller than the orbit. The supratemporal fenestra is poorly preserved.

Premaxilla and Maxilla. The premaxilla is fused with the maxilla and the suture is obliterated, thus the boundary between the two bones cannot be traced. Consequently, the premaxillary and maxillary teeth count is unknown. There is no premaxillary crest, as in all other istiodactylids and Haopterus gracilis. The rostral tip of the premaxilla exhibits a slight dorsal deflection of palatal anterior tip (Fig. 4), as evidenced from the uplifted positions of the two anteriormost teeth. This is similar to what has already been reported for Cimoliopterus and anhanguerians (see Rodrigues \& Kellner, 2013).

Nasal and Lacrimal. The nasal and lacrimal form the anterodorsal margin of the orbit and the posterodorsal margin of the nasoantorbital fenestra. The anterior end of the nasolacrimal coincides with the highest point of the nasoantorbital fenestra, as in both specimens of $N$. ignaciobritoi and also Ikrandraco avatar (Wang XL et al., 2005; Wang L et al., 2006; Andres \& Ji, 2006; Lü et al., 2008; Wang XL et al., 2015), but unlike Istiodactylus latidens and most anhanguerians (e.g., Anhanguera, Tropeognathus and Hamipterus), except for Ludodactylus sibbicki, in which the highest point is posterior to the anterior end of the nasolacrimal (Campos \& Kellner, 1985; Wellnhofer, 1987; Kellner \& Tomida, 2000; Wang XL et al., 2014; Frey et al., 2003). A nasal descending process cannot be seen in BPMC-0204, possibly because it is still covered by rock. There are no traces of an orbital process of the lacrimal invading the orbit, but the posterior margin 
201 of the lacrimal is slightly damaged and a small process similar to the one seen in the holotype of 202 N. ignaciobritoi may had been present and got lost (see Wang XL et al., 2005; Wang L et al., 2006; 203 Andres \& Ji, 2006; Lü et al., 2008). The lacrimal contacts the lacrimal process of the jugal at about 204 the mid-height of the posterior margin of the nasoantorbital fenestra. The nasal is bordered dorsally 205 by the premaxilla and by the prefrontal posteroventrally.

206

Jugal and Quadratojugal. The jugal is partially preserved, missing part of the maxillary process and the base of the lacrimal process. The jugal sends a postorbital process to contact the postorbital, separating the orbit and the infratemporal fenestra. Posteriorly, the jugal contacts the quadratojugal, which forms the anteroventral of the infratemporal fenestra.

Quadrate. Sutures at the lateral surface of the quadrate are unclear. It is unclear whether the articulation with the mandible is helical or not. The mid-region of the quadrate is lost. The dorsal portion of the quadrate contacts the quadratojugal anteriorly and the squamosal dorsally. The quadrate is inclined backwards at an angle of $150^{\circ}$, unlike both specimens of $N$. ignaciobritoi (Fig. 3 ), in which it slopes at $\sim 160^{\circ}\left(160^{\circ} 4^{\prime}\right.$ in the holotype; Wang XL et al., 2005 ; $163^{\circ}$ in the referred specimen; Wang L et al., 2006).

Prefrontal. The prefrontal is a small bone that forms the anterodorsal margin of the orbit, contacting the nasolacrimal. A suture between these two bones can be seen anteroventrally. The dorsoposterior tip of this bone contacts the frontal.

Frontal. The frontal seems to be fused with the premaxilla and parietal, with no visible sutures. It is unclear whether the posterodorsal extension of the frontal forms a blunt and low frontoparietal crest as in Anhanguera (see Kellner \& Tomida, 2000) or not.

Parietal and Squamosal. The parietal and squamosal are poorly preserved, especially the latter. The squamosal outline cannot be properly identified. The parietal preserves a shallow depression in its surface that corresponds to the medial wall of the supratemporal fenestra. The dorsal limits of this fossa level with the orbit and extend ventrally to the region of contact between the squamosal and the postorbital.

Postorbital. The postorbital is slender and does not exhibit a triangular shape, oppositely to the triangular condition that is seen in anhanguerids (e.g. Kellner \& Tomida, 2000). Instead, it is like a three-pointed star (= concave equilateral hexagon) as in Haopterus gracilis (see Wang XL \& Lü, 
230 2001); that is, is essentially composed of three connected processes. The anterior region of the 231 postorbital which is formed by the frontal and jugal processes, is arched and forms the posterior

232

233

234

235

236

237

238

239

240

241

242

243

244

245

246

247

margin of the orbit. The squamosal process is shorter than the other processes and separates the supra and infratemporal fenestrae. There is no orbital process of the postorbital invading the orbit, unlike Istiodactylus (Andres \& Ji, 2006; Witton, 2012).

Palatal elements. Due to crushing, some palatal elements are visible in dorsal view, though few details can be observed. The vomers form a long, slender bony bar that separates the choanae, as in Hongshanopterus lacustris (see Wang XL et al., 2008a). Of the pterygoid, only the medial process can be seen. It is large and plate-like as that of Hongshanopterus lacustris (see Wang XL et al., 2008a) and, to a lesser extent, the anhanguerids, in which the process is also broad but less medially expanded (e.g., Campos \& Kellner, 1985; Frey et al., 2003). This differs from the slender medial processes of the pterygoid of azhdarchoids (e.g., Pinheiro \& Schultz, 2012; Kellner, 2013; Pêgas et al., 2018) or those of the referred specimen of $N$. ignaciobritoi (see Wang L et al., 2006; Lü et al., 2008) and Ikrandraco avatar (see Wang XL et al., 2015).

Dentary. The dentaries are fused rostrally forming a symphysis that accounts for $36 \%$ of total mandibular length, which is $240 \mathrm{~mm}$ long. The dorsal surface of the symphysis presents a deep and broad median sulcus that extends anteriorly up to the level of the first pair of teeth (Fig. 5). The rostral tip of the dentary symphysis has an odontoid (pseudotooth), that is located between the first pair of teeth, is smaller than the adjacent tooth crowns and is dorsally directed. The odontoid lacks the neurovascular foramen piercing its surface in the referred specimen of $N$. ignaciobritoi (see Wang L et al., 2006). The odontoid has the same orientation as that of Istiodactylus latidens (see Witton, 2012; Martill, 2014) and Lonchodraco giganteus (see Rodrigues \& Kellner, 2013, fig. 4E-F), unlike the sub-horizontal odontoids of both specimens of $N$. ignaciobritoi (see Wang XL et al., 2005; Wang L et al., 2006) and Ikrandraco avatar (see Wang XL et al., 2015). The symphysis presents 11 tooth positions per side.

Surangular, Articular and Angular. The lateral surface of the posterior region of the right mandibular ramus is composed by the surangular, angular and articular. A suture separates the long anterior process of the surangular from the dentary dorsally. Posteriorly, the surangular becomes deeper and is sutured with the angular. The boundary between the angular and the dentary, however, cannot be distinguished, nor the boundary between the angular and the articular. The

Peer) reviewing PDF | (2019:04:37231:3:0:NEW 9 Aug 2019) 
260 articular forms the posterior part of the mandible, including the articular surface for the quadrate

261 and the retroarticular process, which is pointed, dorsoventrally low and distally tapering.

262 Hyoid. Only the right ceratobranchial I is exposed along the ventral margin of the right mandibular 263 ramus (Fig. 1). A small portion of the posterior part is missing. The ceratobranchial I is a long rod264 like bone extending along the whole length of the mandibular rami.

265 Dentition. There are 12 tooth positions along the right side of the upper jaw and 11 tooth positions along each side of the lower jaw, with an inferred total count of 46 tooth positions. The first two teeth of the upper jaw (which are presumably premaxillary teeth) are procumbent. The first tooth forms an angle of $130^{\circ}$ with the main axis of the rostrum, while the second forms an angle of $123^{\circ}$. The third tooth is also slightly procumbent, forming an angle of $100^{\circ}$ with the palatal plane. All subsequent teeth are perpendicular to the main axis of the rostrum. The first two dentary teeth are also slightly procumbent. The last two alveoli of the right maxilla are empty, and the last one is placed just anterior to the level of the rostral end of the nasoantorbital fenestra. All of the crowns are triangular in labiolingual view and labiolingually compressed, as typical of the Istiodactylidae. The base of the crowns is mesiodistally inflated. The lingual surface of the crown is concave with a well-marked basoapical depression and a low transversal convexity at the base, that forms a lingual cingulum. The labial surface is mostly convex with a shallow concavity in the middle of the basal part of the crown. No carinae are present along the mesial and distal cutting margins of the crowns. The same features occur in the crowns of the holotype of $N$. ignaciobritoi. The teeth exhibit a slight constriction between crown and root (Fig. 5). This feature is also shared with $N$. ignaciobritoi (see Wang XL et al., 2005).

The first nine pairs of teeth of the upper jaw are large and subequal in size. Their apicobasal total length of their crowns is about $12 \mathrm{~mm}$ and the crown apicobasal length is about $7 \mathrm{~mm}$, and the mesiodistal width of the socket is $4 \mathrm{~mm}$. The smallest crown is $6 \mathrm{~mm}$ in apicobasal length and 2 $\mathrm{mm}$ in mesiodistal width.

$N$. luei sp. nov. also presents an interesting pattern of tooth replacement. Two teeth occur in the tenth alveolus of the right dentary: a large functional one and a not yet fully erupted replacement tooth. The replacement tooth was erupting anterolabially to the functional tooth, instead of posterolingually as reported in other pterodactyloid pterosaurs like Anhanguera (see Kellner \& Tomida, 2000; Fastnacht, 2001) and 'Cearadactylus' ligabuei (see Dalla Vecchia, 1993). 
290 Cervical vertebrae. Seven cervical vertebrae are preserved, including the atlas-axis complex 291 (although the atlas itself cannot be identified). They are articulated, except for the 7th vertebra, 292 which is disarticulated but still contacting the 6th vertebra. The 3rd cervical, with $38.4 \mathrm{~mm}$, is 293 longer than the 4th through 7th cervicals which are of similar length. The neural spine is damaged 294 in most cervicals, except that of the 4th vertebra, which is high and with a peculiar shape (its anterior margin is anteriorly inclined). The apex of the neural spine is gently rounded. The postzygapophyses are posterodorsally oriented. The centrum extends posterior to the postzygapophyses. In the 3rd to the 7th cervicals, a large pneumatic foramen can be seen on the posterior half of the centrum below the neural arch.

299

300

301

302

303

304

\section{Phylogenetic analysis results}

The phylogenetic analysis by parsimony produced 51 most parsimonious trees with a minimum length of 360 steps, with minimum consistency index of 0.642 and retention index of 0.862 . As suspected by Witton (2012), Hongshanopterus lacustris and Haopterus gracilis were found to be closely related to the Istiodactylidae in the strict consensus tree (Fig. 6), but they fall outside them. The Istiodactylidae have been defined by Andres et al. (2014) as the least inclusive clade containing Istiodactylus latidens Seeley 1901 and Nurhachius ignaciobritoi Wang XL et al. 2005. In the strict consensus tree (Fig. 6), the Istiodactylidae contain Nurhachius, Liaoxipterus brachyognathus and Istiodactylus. N. ignaciobritoi and N. luei sp. nov. were recovered as sister taxa. Istiodactylus latidens and I. sinensis were also recovered as sister taxa and Liaoxipterus brachyognathus is the sister-taxon of Istiodactylus.

Istiodactylus has the following five synapomorphies: presence of a suborbital opening (character 11, state 1); prenarial portion of the rostrum less than $20 \%$ the skull length (character 25, state 0 ); presence of an orbital process in the jugal (character 56, state 1); and sharp carinae in the teeth (character 96, state 1). Istiodactylus shares with Liaoxipterus brachyognathus the following synapomorphies: subparallel lateral margins of the jaws (character 24, state 1); mandibular symphysis shorter than $33 \%$ of the mandible length (character 78 , state 1); and rounded outline of the rostral end of the mandible (character 79 , state 0 ).

The genus Nurhachius is characterized by the following five synapomorphies: piriform orbit (character 7, state 2); cranio-mandibular articulation-under the anterior margin of orbit (character 
31958 , state 2); dorsal deflection of the palatal anterior tip (character 71, state 1); teeth crowns with 320 labial and lingual depressions (character 100, state 1); teeth with a mesiodistal constriction 321 between crown and root (character 101, state 1). The presence of a dorsal deflection of the palatal 322 anterior tip represents a homoplasy with Anhangueria + Cimoliopterus.

323 The Istiodactylidae share the following seven synapomorphies: ventral margin of the nasoantorbital fenestra longer than $40 \%$ of skull length (character 4, state 1); orbit reaching high in the skull, with the dorsal margin surpassing the dorsal margin of the nasoantorbital fenestra (character 10, state 1); skull height (exclusive of cranial crests) over $25 \%$ of the jaw length (character 23, state 1); lacrimal process of jugal inclined posteriorly (character 54, state 2); helical jaw-joint absent (character 59, state 0); palatal occlusal surface: strong palatal ridge confined to the posterior portion of the palate (character 71, state 3 ); teeth confined to about the anterior third of the jaws (character 86 , state 3 ).

Hongshanopterus lacustris results to be the sister-taxon of the Istiodactylidae. The clade Hongshanopterus lacustris + Istiodactylidae presents two synapomorphies: tooth crowns strongly compressed laterally (character 95, state 2); and mesial crowns under twice as long as wide (character 97, state 0 ).

Haopterus gracilis results as the sister-taxon of Hongshanopterus lacustris +Istiodactylidae, sharing teeth that are confined to the anterior half of the jaws (character 86, state 2).

The Istiodactylidae, Hongshanopterus lacustris and Haopterus gracilis share with Ikrandraco avatar four synapomorphies: narrow lacrimal process of jugal (character 53, state 1); quadrate inclination relative to the ventral margin of the skull-is $150^{\circ}$ or more (character 57 , state 3 ); tooth crowns slightly compressed laterally (character 95, state 2); lingual cingulum present at the base of tooth crown (character 102, state 1). The last two character states are also shared with Lonchodraco giganteus.

343 Bremer support values were 1 for the genus Istiodactylus, 3 for Istiodactylus + Liaoxipterus, 5 for 344 the genus Nurhachius, 3 for Istiodactylidae, 3 for Hongshanopterus + Istiodactylidae, 1 for Haopterus + (Hongshanopterus + Istiodactylidae), 1 for Ikrandraco + Lonchodraco and 2 for the 346 clade that joins all of these taxa. 


\section{Discussion}

349 For over a century, Istiodactylus latidens was the only known istiodactylid (Witton, 2012). In the last 15 years, three new istiodactylids have been reported from the Jiufotang Formation of China: N. ignaciobritoi (described in 2005); Istiodactylus sinensis and Longchengpterus zhaoi (both described in 2006); and Liaoxipterus brachyognathus (originally described in 2005 as a purported ctenochasmatid and referred to the Istiodactylidae in 2008; Dong \& Lü, 2005; Wang XL et al., 2005; Wang L et al., 2006; Andres \& Ji, 2006; Lü et al., 2008). However, the validity of some of them is debated. According to Lü et al. (2008), the holotypes of Longchengpterus zhaoi and $N$. ignaciobritoi are indistinguishable, sharing general skull shape and tooth morphology. Therefore, Longchengpterus zhaoi was considered a junior synonym of $N$. ignaciobritoi by Lü et al. (2008). Witton (2012) provisionally considered both of them as valid and distinct taxa, coding them separately in his phylogenetic analysis though without discussing it further. They were coded differently as for tooth count and spacing, with Nurhachius that was considered to have more numerous and more spaced teeth. However, both specimens exhibit a similar number of upper teeth (13 pairs in the holotype of $N$. ignaciobritoi and 12 pairs in L. zhaoi) and similar spacing (Wang XL et al., 2005; Lü et al., 2008). Furthermore, the holotypes and only specimens of Longchengpterus zhaoi and N. ignaciobritoi share further features that are unique within istiodactylids (Fig. 3): the high quadrate inclination $\left(\sim 160^{\circ}\right)$, the reduced medial process of the pterygoid, the upper dentition ending at the level of the nasoantorbital fenestra, and the subhorizontal odontoid in the mandibular symphysis. Therefore, we follow Lü et al. (2008) in considering Longchengpterus zhaoi as a junior synonym of $N$. ignaciobritoi.

$N$. luei sp. nov. is an istiodactylid based on the following features: nasoantorbital fenestra longer than $40 \%$ of skull length, dentary symphysis less than $33 \%$ of mandible length; and triangular, labiolingually compressed tooth crowns. It shares with $N$. ignaciobritoi a piriform orbit, a dorsally deflected palatal anterior tip, a cranio-mandibular articulation positioned under the anterior margin of the orbit (Fig. 3), tooth crowns with labial and lingual depressions, and teeth with mesiodistal constrictions between crown and root (Fig. 5; 6). All these features are present in the holotype of $N$. ignaciobritoi, while in the referred specimen the dorsal deflection of the palatal anterior tip 
376

377

378

379

cannot be assessed as the rostrum tip is missing. Concerning the crown, with both a labial and a lingual depression, we note that this morphology is reflected in the shape of the alveoli in $N$. ignaciobritoi, with concave labial and lingual margins (Fig. 5). The dorsal deflection of the palatal anterior tip is present in the rostral tip of the skull of the holotype of $N$. ignaciobritoi, as evidenced from the dorsal position of the first pair of alveoli, (see Fig. 4C-D), although it was not mentioned in the original description (Wang XL et al., 2005), as well as in the holotype of $N$. luei. This character was utilized in a data matrix for the first time by Rodrigues \& Kellner (2013), and resulted to be a synapomorphy of Anhangueria + Cimoliopterus. According to our phylogenetic analysis (Fig. 7), this feature was independently acquired by Nurhachius and Anhangueria + Cimoliopterus.

$N$. luei sp. nov. differs from $N$. ignaciobritoi in the following features: the quadrate is inclined at $150^{\circ}$ instead of the $\sim 160^{\circ}$ of $N$. ignaciobritoi; the medial process of the pterygoid is broad and plate-like, whereas it is reduced in N. ignaciobritoi (see Fig. 3); the dorsal median sulcus of the mandibular symphysis extends up to the first pair of teeth, whereas it reaches the sixth pair of teeth in N. ignaciobritoi (see Fig. 5); the odontoid (pseudotooth) lacks a lateral foramen, whereas a foramen is present in the referred specimen of $N$. ignaciobritoi (see Martill, 2014, fig. 7C-D); the odontoid has a blunt occlusal surface, whereas the surface is sharp in N. ignaciobritoi (Fig. 5); the odontoid is dorsally directed, whereas it is anterodorsally directed in $N$. ignaciobritoi (but see Martill, 2014, p. 57, right column, lines 21-23); and the ceratobranchial I of the hyoid apparatus accounts for $60 \%$ of the mandibular length, whereas it accounts for $35 \%$ of the mandibular length in N. ignaciobritoi (Fig. 5).

Concerning quadrate inclination, we do not regard this variation as intraspecific as the variation does not surpass $3^{\circ}$ in the archaeopterodactyloid Pterodactylus antiquus (specimens BSPG AS I 739, BSPG 1929 I 18, BMMS 7; see Bennett, 2013; Vidovic \& Martill, 2014), 30 in the anhanguerian Hamipterus tianshanensis (IVPP V18931.1, holotype, and IVPP V18935.1, paratype; see Wang XL et al., 2014), $5^{\circ}$ in Aerodactylus scolopaciceps (BSPG 1883 XVI 1, BSPG 1937 I 18, BSPG AS V 29 a/b; see Vidovic \& Martill, 2014), and is less than $6^{\circ}$ in Pteranodon longiceps (specimens YPM 1177, USNM 13656, KUVP 2212, KUVP 27821) and also in Pteranodon sternbergi (specimens FHSM VP 339, YPM 1179, UALVP 24238; see Bennett, 1994; 2001). Quadrate inclination has indeed been regarded as diagnostic before for tapejarids (Kellner, 
406

407

408

409

410

411

412

413

414

415

416

417

418

419

420

421

422

423

424

425

426

427

428

429

430

431

432

433

434

2013) and Pteranodon (Bennett, 1994). We regard this feature as potentially diagnostic at least until further specimens of each species of Nurhachius are found.

Both specimens of $N$. ignaciobritoi come from the upper part of the Jiufotang Formation (see Wu et al., 2018), while the holotype of $N$. luei comes from the lowermost part of the Jiufotang Formation. This stratigraphic distribution might be suggestive of an anagenetic link between the two species, similar to the case of Pteranodon longiceps (from the upper Smoky Hill Chalk) and Pteranodon sternbergi (from the lower Smoky Hill Chalk) according to Bennett (1994), but see taxonomic controversies (Kellner, 2010; 2017; Martin-Silverstone et al., 2017; Acorn et al., 2017). The same has been speculated as a possible explanation for the occurrence of multiple species of Anhanguera (Pinheiro \& Rodrigues, 2017), Thalassodromeus and Tupuxuara (Pêgas et al., 2018) in the Romualdo Formation. However, these cases still lack stratigraphic control for support, and the time resolution of the Romualdo Formation is still in question (see Pinheiro \& Rodrigues, 2017).

Wang XL et al. (2008a) were unable to differentiate Liaoxipterus brachyognathus from Longchengpterus zhaoi, and suggested that Longchengpterus zhaoi could be a junior synonym of Liaoxipterus brachyognathus. However, as observed by Lü et al. (2008), the rostral end of the mandibular symphysis is rounded in Liaoxipterus brachyognathus (in dorsal view, as it is in Istiodactylus latidens), whereas it is triangular in "Longchengpterus zhaoi". Furthermore, as coded by Andres et al. (2014), both jaws show an attenuated taper (in occlusal view) in Longchengpterus zhaoi, while the lateral margins of the lower jaw are sub-parallel in Liaoxipterus brachyognathus (Fig. 8A) as in Istiodactylus latidens. Additionally, the mandibular symphysis of Liaoxipterus brachyognathus is relatively stouter than that of Longchengpterus zhaoi: their length/width ratios are 0.43 and 0.27 , respectively. It is worthy of being noticed that the mandibular symphysis of Longchengpterus zhaoi is incorrectly drawn in Martill (2014, fig. 7B), as resulting to be much shorter than it is. The actual configuration can be clearly assessed in the description by Lü et al. (2008) and in Fig. 5A. We thus follow Lü et al. (2008) and Witton (2012) in considering Liaoxipterus brachyognathus as distinct from Longchengpterus zhaoi, which we consider as a junior synonym of $N$. ignaciobritoi.

Lü et al. (2008) and Witton (2012) noticed that comparison between Liaoxipterus brachyognathus 
435

436

437

438

439

440

441

442

443

444

445

446

447

448

449

450

451

452

453

454

455

456

457

458

459

460

461

462

463

and Istiodactylus sinensis is very limited because the former is represented by a mandible exposed in occlusal view, while the latter is a partial skeleton including a mandible exposed in lateral view. However, Liaoxipterus brachyognathus differs from Istiodactylus in the lack of mesial carinae, according to Lü et al. (2008) and the dataset of Andres et al. (2014). We thus follow these authors in considering Liaoxipterus brachyognathus as a valid taxon.

According to our phylogenetic analysis, Istiodactylus is monophyletic, comprising I. latidens and I. sinensis. Liaoxipterus brachyognathus is the sister-taxon of Istiodactylus, and Nurhachius is the sister-taxon of Liaoxipterus brachyognathus + Istiodactylus, in agreement with the results of the phylogenetic hypothesis published by Longrich et al. (2018). In our analysis, N. luei results to be the sister-taxon of $N$. ignaciobritoi, supporting their congeneric status. The relationships within the Istiodactylidae obtained in our analysis are similar to those found by Andres et al. (2014), but Longchengpterus zhaoi is not the sister-taxon of $N$. ignaciobritoi in the cladogram of figure S2 of Andres et al. (2014).

Haopterus gracilis was first described by Wang XL \& Lü (2001) and referred to the Pterodactylidae. However, it resulted to be close to Istiodactylus latidens in the $50 \%$ majority-rule tree by Lü et al. (2008) and formed a polytomy with Nurhachius and Istiodactylus in the strict consensus tree by Lü et al. (2009). Hongshanopterus lacustris-was described by Wang XL et al. (2008a) and interpreted as a primitive istiodactylid. In the strict consensus tree by Witton (2012), the Istiodactylidae include Nurhachius igniaciobritoi, Longchengpterus zhaoi, Istiodactylus latidens, Istiodactylus sinensis, and Liaoxipterus brachyognathus. Haopterus gracilis and Hongshanopterus lacustris form a polytomy with Pteranodon longiceps, Coloborhynchus spielbergi and the Istiodactylidae (Witton, 2012).

In the phylogenetic analysis of Andres et al. (2014; fig. S2), Haopterus gracilis results to be a basal eupterodactyloidean and Hongshanopterus a basal ornithocheiromorph. Recently, Holgado et al. (2019) have published a phylogenetic hypothesis in which Hongshanopterus lacustris would be the sister-group of the Istiodactylidae (although it is erroneously reported within this clade as the basal member in their fig. 5A), while Haopterus gracilis would be closer to anhanguerians than to istiodactylids (see Holgado et al., 2019).

In our analysis, Haopterus gracilis and Hongshanopterus lacustris are closely related to the 
464 Istiodactylidae, as found by Lü et al. (2008) and Wang XL et al. (2008a), respectively. 465 Hongshanopterus lacustris results to be the sister-taxon of the Istiodactylidae, as in the analysis 466 by Holgado et al. (2019). Hongshanopterus lacustris shares with the istiodactylids the presence of 467 labiolingually compressed teeth with triangular crowns. Haopterus gracilis results to be the sister468 taxon of Hongshanopterus lacustris + Istiodactylidae, a relationship that is supported by the 469 possession of a dentition restricted to the anterior half of the jaws.

470

Haopterus, Hongshanopterus and istiodactylids share also the presence of a lingual cingulum in the tooth crown, a feature that occurs also in Ikrandraco avatar. A lingual cingulum can be seen in Nurhachius luei and N. ignaciobritoi (Fig. 6). The same feature has been previously reported for Liaoxipterus brachyognathus (see Lü et al., 2008) and depicted for Ikrandraco avatar (see the second figure of Wang XL et al., 2015). In Haopterus gracilis, the labiodistal view of the third right upper tooth presents a lingually oriented convexity that also suggests the presence of this feature (Fig. 8).

Ikrandraco avatar shares with istiodactylids also a narrow lacrimal process of the jugal and a quadrate inclined at $150^{\circ}$ or over (the inclination of the quadrate is unknown in Haopterus gracilis and Hongshanopterus lacustris). Ikrandraco avatar and Haopterus gracilis also exhibit a certain degree of labiolingual compression of the teeth, at least in the distal part of the dentition (Wang XL \& Lü, 2001; Wang XL et al., 2015), though not to the same degree seen in the istiodactylids and Hongshanopterus. The last two mandibular alveoli preserved in the holotype of Lonchodraco giganteus (the sister-taxon of Ikrandraco avatar in our analysis) are also labiolingually narrow (see Martill, 2011; Rodrigues \& Kellner, 2013).

Furthermore, Ikrandraco avatar and Lonchodraco giganteus also share with istiodactylids the presence of an odontoid, which is anterodorsally oriented in the former and dorsally oriented in the latter (see Rodrigues \& Kellner, 2013; Wang XL et al., 2015).

A close relationship among Ikrandraco avatar, Lonchodraco giganteus and istiodactylids is found here for the first time. Ikrandraco avatar formed a polytomy with the Istiodactylidae, Cimoliopterus and the Anhangueria in the phylogenetic analysis by Wang XL et al. (2015) and Lonchodraco giganteus is outside the Lanceodontia in the phylogenetic analysis by Longrich et al. (2018). 
493

494

495

496

497

498

499

500

501

502

503

504

505

506

507

508

509

510

511

512

513

514

515

516

517

518

519

520

521

522

Archaeoistiodactylus linglongtaensis is based on the sole holotype (JPM04-0008), including fragments of skull and one displaced maxillary tooth, a partial lower jaw in occlusal view with two teeth in place, an almost complete forelimb, a femur and a tibia. It is from the Middle Jurassic (Bathonian-Oxfordian) Tiaojishan Formation. A. linglongtaensis was described by Lü \& Fucha (2010) who interpreted it as the "ancestor form of the known istiodactylid pterosaur [sic]" (Lü \& Fucha, 2010, p. 113). Lü \& Fucha (2010) observed that JPM04-0008 and the istiodactylids share teeth with triangular crowns and an odontoid (pseudotooth) on the mandibular symphysis. That odontoid was mistaken for a mid-line, unpaired tooth by Sullivan et al. (2014), but it had been explicitly described as a bony process by Lü \& Fucha (2010, p. 116). Lü \& Fucha (2010) also observed that the single maxillary tooth is recurved as in Hongshanopterus lacustris, and reported the presence of a warped deltopectoral crest in the humerus, which is a diagnostic feature of the Pteranodontoidea (Kellner, 2003). They noted that A. linglongtaensis differs from istiodactylids and all other pterodactyloids in the relatively short fourth metacarpal and in the presence of tibia, and second and third phalanges of the wing digit with subequal lengths. If actually a pterodactyloid, it would represent one of the oldest occurrences of the Pterodactyloidea, being coeval or even older than the Callovian-Oxfordian basalmost pterodactyloid Kryptodrakon progenitor (see Andres et al., 2014).

Its identification as a pterodactyloid was disputed by Martill \& Etches (2013), who affirmed that JPM04-0008 is probably a badly preserved specimen of Darwinopterus, though they did not present any evidence to support this statement. According to Sullivan et al. (2014), the short fourthmetacarpal, the long humerus and short first wing phalanx are typical of non-pterodactyloid pterosaurs (see Kellner, 2003; Unwin, 2003; Andres et al., 2010), thus JPM04-0008 is not a pterodactyloid. These features united to the presence of a confluent nasoantorbital fenestra in JPM04-0008, led Sullivan et al. (2014) to interpret A. linglongtaensis as a basal monofenestratan.

However, A. linglongtaensis has never been included in any phylogenetic analysis to test its basal monofenestratan affinity, thus it was included in the analysis performed in this paper. Our results (Fig. 6) confirm the interpretation by Sullivan et al. (2014). Archaeoistiodactylus linglongtaensis lacks the following pterodactyloid features: humerus length under 1.5 times metacarpal IV length; ulna under double the length of metacarpal IV; and femur subequal to or shorter than metacarpal IV. The humerus of JPM04-0008 is crushed and the original orientation of the deltopectoral crest 
523

524

525

526

527

528

529

530

531

532

533

534

535

536

537

538

539

cannot be assessed. Differently from pterodactyloids, the deltopectoral crest of JPM04-0008 is confined to the proximal region of the humerus (Wang XL et al., 2009). A. linglongtaensis also lacks pneumatic foramina on the centra of the mid-cervical vertebrae, which is a diagnostic feature of the Dsungaripteroidea (the least inclusive clade containing Nyctosaurus and Quetzalcoatlus, which includes also the Istiodactylidae; Kellner, 2003; Andres et al., 2014). Furthermore, $A$. linglongtaensis exhibits low neural spines, like wukongopterids (see Wang XL et al. 2009; 2010; Lü et al., 2009; 2011; Cheng et al., 2017) and unlike istiodactylids (see Wang L et al., 2006; Lü et al., 2008).

The dentition of $A$. linglongtaensis is indeed reminiscent of that of the Istiodactylidae due to the short triangular aspect of the crowns in labiolingual view. However, this feature is also present in the wukongopterids Wukongopterus lii, Darwinopterus robustodens, Darwinopterus linglongtaensis and Kunpengopterus sinensis, though not in Darwinopterus modularis (see Wang XL et al. 2009; 2010; Lü et al., 2009; 2011; Cheng et al., 2017). Furthermore, in A. linglongtaensis the alveoli are circular (Lü \& Fucha, 2010), as in wukongopterids, not labiolingually compressed triangular teeth as in istiodactylids. The presence or absence of an odontoid in the lower jaw cannot be confidently assessed in Wukongopterus and Darwinopterus, but can be seen in a specimen referred to Kunpengopterus sinensis (see Cheng et al., 2017), in convergence with the istiodactylids. Finally, A. linglongtaensis shares with Darwinopterus and Kunpengopterus, but not with Wukongopterus, the subequal in length second and third phalanges of the wing digit. Thus, A. linglongtaensis may be closely related to Darwinopterus or Kunpengopterus. In our analysis, A. linglongtaensis falls in a polytomy with Darwinopterus linglongtaensis, D. robustodens and Kunpengopterus sinensis (Fig. 6). However, we were unable to access the specimen first-hand and further scrutiny is desirable in order to confirm or deny this affinity.

\section{Conclusions}

The new specimen here described represents the second species for the genus Nurhachius, previously restricted to its type-species $N$. ignaciobritoi. A slight dorsal deflection of the palatal anterior tip revealed to be a synapomorphy of $N$. ignaciobritoi and $N$. luei. That feature was previously thought to be restricted to the Anhangueria and Cimoliopterus. Unlike other 
552 pterodactyloids, the holotype of $N$. luei sp. nov. shows an anterolabial tooth replacement. The

553 position of Hongshanopterus lacustris and Haopterus gracilis as close taxa to the Istiodactylids is

554

555

556

557

558

559

560 supported by the performed phylogenetic analysis. Ikrandraco avatar and Lonchodraco giganteus resulted to be sister taxa, and closer to istiodactylids than to other lanceodontians. The phylogenetic analysis supports the reinterpretation of Archaeoistiodactylus linglongtaensis as a non-pterodactyloid monofenestratan, probably a wukongopterid.

\section{Acknowledgements}

We thank Shu'an Ji and Xuefang Wei (IG-CAGS, Institute of Geology, Chinese Academy of Geological Sciences) for the help all along. Thanks to Cunyu Liu (BPMC, Beipiao Pterosaur Museum of China), Dongyu Hu (SNU, Shenyang Normal University), Xiaolin Wang \& Shunxing Jiang (IVPP, Institute of Vertebrate Paleontology and Paleoanthropology) for access to specimens under their care. RVP thanks Kamila Bandeira, Lucy Souza and Natan Brilhante (Museu Nacional/UFRJ) for technical help with image software. We thank Zoological Museum (SNM), Copenhagen University for hospitality during X. Y. Zhou's and R. V. Pêgas' stay in Copenhagen with access to important pterosaur specimens, and for M. E. C. Leal's status as guest researcher, and N. Bonde's work space as emeritus (and Senior Scientist, Fur Museum). Thanks to Fabio M. Dalla Vecchia, Felipe Pinheiro, Chris Bennett and an anonymous reviewer for their thoughtful and constructive critiques; and to editor Graciela Piñeiro for her kind attention.

\section{References}

Acorn JH, Martin-Silverstone E, Glasier JRN, Mohr S, Currie PJ. 2017. Response to Kellner (2017) 'Rebuttal of Martin-Silverstone, E., JRN Glasier, JH Acorn, S. Mohr, and PJ Currie, 2017'. Vertebrate Anatomy Morphology Palaeontology 3: 90-92.

Andres B, Ji Q. 2006. A new species of Istiodactylus (Pterosauria, Pterodactyloidea) from the Lower Cretaceous of Liaoning, China. Journal of Vertebrate Paleontology 26(1): 70-78.

Andres B, Clark JM, Xu X. 2010. A new rhamphorhynchid pterosaur from the Upper Jurassic of Xinjiang, China, and the phylogenetic relationships of basal pterosaurs. Journal of Vertebrate Paleontology 30(1): 163-187.

Andres B, Clark JM, Xu X. 2014. The earliest pterodactyloid and the origin of the group. Current 
Biology 24(9): 1011-1016.

Bennett SC. 1994. Taxonomy and systematics of the Late Cretaceous pterosaur Pteranodon (Pterosauria, Pterodactyloidea). Occasional papers of the Naturtal Natural History Museum/The University of Kansas (169):1-70.

Bennett SC. 2001. The osteology and functional morphology of the Late Cretaceous pterosaur Pteranodon Part I. General description of osteology. Palaeontographica Abteilung A 2001: 1-112.

Bennett SC. 2013. New information on body size and cranial display structures of Pterodactylus antiquus, with a revision of the genus. Paläontologische Zeitschrift 87(2): 269-289.

Campos DA, Kellner AWA. 1985. Panorama of the flying reptiles study in Brazil and South America. Anais da Academia Brasileira de Ciências 57: 453-466.

Chang MM, Chen PJ, Wang YQ, Wang Y, Miao DS. eds. 2003. The Jehol Biota. Shanghai Sci. \& Tech. Publ. 208 pp.

Chang SC, Zhang HC, Renne PR, Fang Y. 2009. High-precision 40Ar/39Ar age for the Jehol Biota. Palaeogeography, Palaeoclimatology, Palaeoecology 280: 94-104.

Cheng X, Jiang SX, Wang XL, Kellner AWA. 2017. Premaxillary crest variation within the Wukongopteridae (Reptilia, Pterosauria) and comments on cranial structures in pterosaurs. Anais da Academia Brasileira de Ciências 89(1): 119-130.

Dalla Vecchia FM. 1993. Cearadactylus? ligabuei, nov. sp., a new Early Cretaceous (Aptian) pterosaur from Chapada do Araripe (Northeastern Brazil). Bolletino della Societa Paleontologica Italiana 32: 401-409.

Dong ZM, Lü JC. 2005. A new ctenochasmatid pterosaur from the Early Cretaceous of Liaoning Province. Acta Geologica Sinica 79(2): 164-167.

Dong ZM, Sun YW, Wu SY. 2003. On a new pterosaur from the Lower Cretaceous of Chaoyang Basin, Western Liaoning, China. Global Geology 22(1): 1-8.

Eberth DA, Russell DA, Braman DR, Deino AL. 1993. The age of the dinosaur bearing sediments at Tebch, Inner Mongolia, People's Republic of China. Canadian Journal of Earth Science 30: 2101-2106.

Fastnacht M. 2001. First record of Coloborhynchus (Pterosauria) from the Santana Formation (Lower Cretaceous) of the Chapada do Araripe, Brazil. Paläontologische Zeitschrift 75(1): 23-26.

Frey E, Martill DM, Buchy MC. 2003. A new crested ornithocheirid from the Lower Cretaceous of northeastern Brazil and the unusual death of an unusual pterosaur. Geological Society, London, Special Publications 217(1): 55-63. 
616 Goloboff PA, Farris JS, Nixon KC. 2008. TNT, a free program for phylogenetic analysis. Cladistics 24(5): 774-786.

Holgado B, Pêgas RV, Canudo JI, Fortuny J, Rodrigues T, Company J, Kellner AWA. 2019. On a new crested pterodactyloid from the Early Cretaceous of the Iberian Peninsula and the radiation of the clade Anhangueria. Scientific reports 9(1): 4940.

Howse SCB, Milner AR, Martill DM. 2001. "Pterosaurs". In Martill D M, Naish D. Dinosaurs of the Isle of Wight. The Palaeontological Association. Pp:324-335.

Jiang SX, Wang XL, Meng X, Cheng X. 2014. A new boreopterid pterosaur from the Lower Cretaceous of western Liaoning, China, with a reassessment of the phylogenetic relationships

Jiang SX, Cheng X, Ma YX, Wang XL. 2016. A new archaeopterodactyloid pterosaur from the Jiufotang Formation of western Liaoning, China, with a comparison of sterna in Pterodactylomorpha. Journal of Vertebrate Paleontology 36 (6): e1212058.

Kaup SS. 1834. Versuch einer Eintheilung der Säugethiere in 6 Stämme und der Amphibien in 6 Ordnungen. Isis von Oken, 1834, cols. 311-315.

Kellner AWA. 2003. Pterosaur phylogeny and comments on the evolutionary history of the group. Geological Society, London, Special Publications 217(1): 105-137.

Kellner AWA. 2010. Comments on the Pteranodontidae (Pterosauria, Pterodactyloidea) with the description of two new species. Anais da Academia Brasileira de Ciências 82(4): 1063-1084.

Kellner AWA. 2013. A new unusual tapejarid (Pterosauria, Pterodactyloidea) from the Early Cretaceous Romualdo Formation, Araripe Basin, Brazil. Earth and Environmental Science Transactions of the Royal Society of Edinburgh 103(3-4): 409-421.

Kellner AWA. 2017. Rebuttal of Martin-Silverstone et al. 2017, 'Reassessment of Dawndraco kanzai Kellner 2010 and reassignment of the type specimen to Pteranodon sternbergi Harksen, 1966'. Vertebrate Anatomy Morphology Palaeontology 3: 81-89.

Kellner AWA, Tomida Y. 2000. Description of a new species of Anhangueridae (Pterodactyloidea) with comments on the pterosaur fauna from the Santana Formation (Aptian-Albian), northeastern Brazil. National Science Museum Monographs 17: ix-137.

Li JJ, Lü JC, Zhang BK. 2003. A new Lower Cretaceous sinopterid pterosaur from the western Liaoning, China. Acta Palacontologica Sinica 42(3): 442-447.

Longrich NR, Martill DM, Andres B. 2018. Late Maastrichtian pterosaurs from North Africa and mass extinction of Pterosauria at the Cretaceous-Paleogene boundary. PLoS Biology 16(3): e2001663.

Lü JC. 2010. A new boreopterid pterodactyloid pterosaur from the Early Cretaceous Yixian Formation of Liaoning Province, northeastern China. Acta Geologica Sinica 84(2): 241-246. 
651 Lü JC, Fucha XH. 2010. A new pterosaur (Pterosauria) from Middle Jurassic Tiaojishan Formation of western Liaoning, China. Global Geology 13 (3/4): 113-118.

Lü JC, Ji Q. 2005. New azhdarchid pterosaur from the Early Cretaceous of western Liaoning. Acta Geologica Sinica 79 (3): 301-307.

Lü JC, Yuan CX. 2005. New tapejarid pterosaur from western Liaoning, china. Acta Geologica Sinica 79(4): 453-458.

Lü JC, Jin XS, Unwin DM, Zhao LJ, Azuma Y, Ji Q. 2006. A new species of Huaxiapterus (Pterosauria: Pterodactyloidea) from the Lower Cretaceous of western Liaoning, China with

Lü J C, Teng F F, Sun D Y, Shen C Z, Li G Q, Gao X, Liu H F. 2016b. The toothless pterosaurs from China. Acta Geologica Sinica, 90 (9): 2513-2525.

Martill DM. 2011. A new pterodactyloid pterosaur from the Santana Formation (Cretaceous) of Brazil. Cretaceous Research 32 (2): 236-243.

Martill DM. 2014. A functional odontoid in the dentary of the Early Cretaceous pterosaur Istiodactylus latidens: Implications for feeding. Cretaceous Research 47: 56-65.

Martill DM, Etches S. 2013. A new monofenestratan pterosaur from the Kimmeridge Clay Formation (Kimmeridgian, Upper Jurassic) of Dorset, England. Acta Palaeontologica Polonica 58(2): 285-295. 
Martin-Silverstone E, Glasier JRN, John H. Acorn JH, Mohr S, Currie PJ. 2017. Redescription of Dawndraco kanzai Kellner, 2010 and reassignment of the type specimen to Pteranodon sternbergi Harksen, 1966. Vertebrate Anatomy Morphology Palaeontology 3: 47-59.

Meng J, Wang YQ, Li CK. 2011. Transitional mammalian middle ear from a new Cretaceous Jehol eutriconodont. Nature 472(7342): 181-185.

Pêgas RV, Costa FR, Kellner AWA. 2018. New information on the osteology and a taxonomic revision of the genus Thalassodromeus (Pterodactyloidea, Tapejaridae, Thalassodrominae). Journal of Vertebrate Paleontology 38(2): e1443273.

Pinheiro FL, Rodrigues T. 2017. Anhanguera taxonomy revisited: is our understanding of Santana Group pterosaur diversity biased by poor biological and stratigraphic control? PeerJ 5: e3285.

Pinheiro FL, Schultz CL. 2012. An unusual pterosaur specimen (Pterodactyloidea,? Azhdarchoidea) from the Early Cretaceous Romualdo Formation of Brazil, and the evolution of the pterodactyloid palate. PLOS ONE 7(11): e50088.

Plieninger F. 1901. Beiträage zur Kenntnis der Flugsaurier. Palaeontographica 48: 65-90.

Rodrigues T, Kellner AWA. 2013. Taxonomic review of the Ornithocheirus complex (Pterosauria) from the Cretaceous of England. ZooKeys 308: 1-112.

Rodrigues T, Jiang SX, Cheng X, Wang X, Kellner AWA. 2015. A new toothed pteranodontoid (Pterosauria: Pterodactyloidea) from the Jiufotang Formation (Lower Cretaceous, Aptain) of China and comments on Liaoningopterus gui Wang and Zhou,2003. Historical Biology 27(6): 782-795.

Seeley HG. 1901. Dragons of the Air. An account of extinct flying reptiles. Methuen, London, xiii p 239 pp.

Sullivan C, Wang Y, Hone DW, Wang YQ, Xu X, Zhang FC. 2014. The vertebrates of the Jurassic Daohugou Biota of northeastern China. Journal of Vertebrate Paleontology 34(2): 243-280.

Unwin DM. 2003. On the phylogeny and evolutionary history of pterosaurs. Geological Society, London, Special Publications 217(1): 139-190.

Vidovic SU, Martill DM. 2014. Pterodactylus scolopaciceps Meyer, 1860 (Pterosauria, Pterodactyloidea) from the Upper Jurassic of Bavaria, Germany: the problem of cryptic pterosaur taxa in early ontogeny. PloS one 9(10): e110646.

Wang L, Li L, Duan Y, Cheng SL. 2006. A new istiodactylid pterosaur from western Liaoning, China. Geological Bulletin of China 25(6): 737-740.

Wang M, Zhou ZH. 2019. A new enantiornithine (Aves: Ornithothoraces) with completely fused 
premaxillae from the Early Cretaceous of China. Journal of Systematic Palaeontology Online edition: 1-14.

Wang X. 2018. Background for the Plant Fossils. Pp. 47-59 in: The Dawn Angiosperms. Springer Geology. Springer, Cham. 334 Pp.

Wang XL, Lü JC. 2001. Discovery of a pterodactylid pterosaur from the Yixian Formation of western Liaoning, China. Chinese Science Bulletin 46(13): 1112-1117.

Wang XL, Zhou ZH. 2003a. A new pterosaur (Pterodactyloidea, Tapejaridae) from the Early Cretaceous Jiufotang Formation of Western Liaoning, China and its implications for biostratigraphy. Chinese Science Bulletin 48(1): 16-23.

Wang XL, Zhou ZH. 2003b. Two new pterodactyloid pterosaurs from the Early Cretaceous Jiufotang Formation of Western Liaoning, China. Vertebrata PalAsiatica 41 (1): 34-41.

Wang XL, Kellner AWA, Zhou ZH, Campos DA. 2005. Pterosaur diversity and faunal turnover in Cretaceous terrestrial ecosystems in China. Nature 437: 875-879.

Wang XL, Campos DA, Zhou ZH, Kellner AWA. 2008a. A primitive istiodactylid pterosaur (Pterodactyloidea) from the Jiufotang Formation (Early Cretaceous), northeast China. Zootaxa 1813: 1-18.

Wang XL, Kellner AWA, Zhou ZH, Campos DA. 2008b. Discovery of a rare arboreal forestdwelling flying reptile (Pterosauria: Pterodactyloidea) from China. Proceedings of the National Academy of Sciences 105(6): 1983-1987

Wang XL, Kellner AWA, Jiang SX, Meng X. 2009. An unusual long-tailed pterosaur with elongated neck from western Liaoning of China. Anais da Academia Brasileira de Ciências 81(4): 793-812.

Wang XL, Kellner AWA, Jiang SX, Cheng X, Meng X, Rodrigues T. 2010. New long-tailed pterosaurs (Wukongopteridae) from western Liaoning, China. Anais da Academia Brasileira de Ciências 82(4): 1045-1062.

Wang XL, Kellner AWA, Jiang SX, Cheng X. 2012. New toothed flying reptile from Asia; close similarities between early Cretaceous pterosaurs faunas from China and Brazil. Naturwissenschaften 99(4): 249-257.

Wang XL, Kellner AWA, Jiang SX, Wang Q, Ma YX, Paidoula Y, Cheng X, Rodrigues T, Meng X, Zhang JL, Li N, Zhou ZH. 2014. Sexually dimorphic tridimensionally preserved pterosaurs and their eggs from China. Current Biology 24(12): 1323-1330.

Wang XL, Rodrigues T, Jiang SX, Cheng X, Kellner AWA. 2015. An Early Cretaceous pterosaur with an unusual mandibular crest from China and a potential novel feeding strategy. Scientific Reports 4: 6329.

Wellnhofer P. 1987. New crested pterosaurs from the Lower Cretaceous of Brazil. Mitteilungen 
der Bayerischen Staatssammlung für Paläontologie und Historische Geologie 27:17-186.

Witton MP. 2012. New insights into the skull of Istiodactylus latidens (Ornithocheiroidea, Pterodactyloidea). PloS one 7(3): e33170.

Wu ZJ, Gao FL, Pan YQ, Wang X. 2018. Division and comparison of Jiufotang Formation of western Liaoning area and its rare fossil bed. Geoscience 32(4): 758-765.

Xu X, Zhou Z, Wang X, Kuang X, Zhang F, Du X. 2003. Four-winged dinosaurs from China. Nature 421(6921): 335.

Yao X, Liao CC, Sullivan C, Xu X. 2019. A new transitional therizinosaurian theropod from the Early Cretaceous Jehol Biota of China. Scientific Reports 9: 5026

Zhou ZH, Barrett PM, Hilton J. 2003. An exceptionally preserved Lower Cretaceous ecosystem. Nature 421(6925): 807-814.

\section{Figures}

Figure 1. Nurhachius luei sp. nov., BPMC-0204, holotype, photograph and line drawing. The scale bar in the line drawing equals $50 \mathrm{~mm}$. Abbreviations: alv, alveolus; an, angular; art, articular; ax, axis; ceI, ceratobranchial I; ch, choana; cv, cervical vertebra; d, dentary; f, frontal; j, jugal; la, lacrimal; m, maxilla; n, nasal; naof, nasoantorbital fenestra; odp, odontoid process; or, orbit; pa, parietal; pf, prefrontal; pmax, premaxilla; po, postorbital; prid, palatal ridge; pty, pterygoid; q, quadrate; vo, vomer. Isolated numbers indicate tooth positions. Note: the visible region of the pterygoid corresponds to the medial process of the bone. Photo by Xuanyu Zhou. Drawing by Maria Eduarda Leal.

\section{Figure 2. Location of the site where BPMC-0204 was found.}

Figure 3. Nurhachius ignaciobritoi specimens, photographs and line drawings. (A) LPM 00023, referred specimen (holotype of Longchengpterus zhaoi), skull and mandible in right lateral view. (B) IVPP V-13288, holotype, skull (mirrored) and mandible in right lateral view. Scale bars equal $50 \mathrm{~mm}$. Abbreviations: art, articular; ch, choana; d, dentary; f, frontal; ios, interorbital septum; j, jugal; ls, laterosphenoid; m, maxilla; n, nasal; op, opisthotic; or, orbit; pa, parietal; pf, prefrontal; pm, premaxilla; prid, palatal ridge; pty, pterygoid; q, quadrate; san, surangular; sq, squamosal. Photographs by Xuanyu Zhou. Drawings by Rodrigo V. Pêgas. 
787 Figure 4. Close view of the rostral tip of Nurhachius species in right lateral view. (A)

Nurhachius luei sp. nov., holotype and (C) Nurhachius ignaciobritoi, IVPP V-13288, holotype, mirrored. (B) and (D), respective schematic drawings of (A) and (C), showing the slight dorsal deflection of the palatal anterior tip (notice the positions of the first and second alveoli in both specimens). Numbers indicate tooth positions. Scale bars equal $20 \mathrm{~mm}$. Photos by Xuanyu Zhou. Drawings by Rodrigo V. Pêgas.

Figure 5. Close view of the dentary symphysis of Nurhachius species. (A) Nurhachius luei sp. nov. holotype in dorsolateral view, and (B) line drawing. (C) Nurhachius ignaciobritoi, LPM 00023, referred specimen, occlusal view, and (D), line drawing. Abbreviations: mg, median groove; odp, odontoid process. Numbers indicate tooth positions. Red arrows indicate the mesiodistal constriction between crown and root. Photos by Xuanyu Zhou. Drawings by Maria Eduarda Leal and Rodrigo V. Pêgas. rectangle indicates the Istiodactylidae and its two closest taxa.

Figure 8. Other istiodactylids and close taxa. (A) Liaoxipterus brachyognathus, CAR-0018, holotype, lower jaw in dorsal view. (B) Haopterus gracilis, IVPP V11726, holotype, skull in right lateral view. (C) Hongshanopterus lacustris, IVPP V14582, holotype, skull in ventral view. All 


\section{Figure 1}

Nurhachius luei sp. nov., BPMC-0204, holotype, photograph and line drawing.

The scale bar in the line drawing equals $50 \mathrm{~mm}$. Abbreviations: alv, alveolus; an, angular; art, articular; ax, axis; cel, ceratobranchial l; ch, choana; cv, cervical vertebra; d, dentary; f, frontal; j, jugal; la, lacrimal; m, maxilla; n, nasal; naof, nasoantorbital fenestra; odp, odontoid process; or, orbit; pa, parietal; pf, prefrontal; pmax, premaxilla; po, postorbital; prid, palatal ridge; pty, pterygoid; q, quadrate; vo, vomer. Isolated numbers indicate tooth positions. Note: the visible region of the pterygoid corresponds to the medial process of the bone. Photo by Xuanyu Zhou. Drawing by Maria Eduarda Leal. 


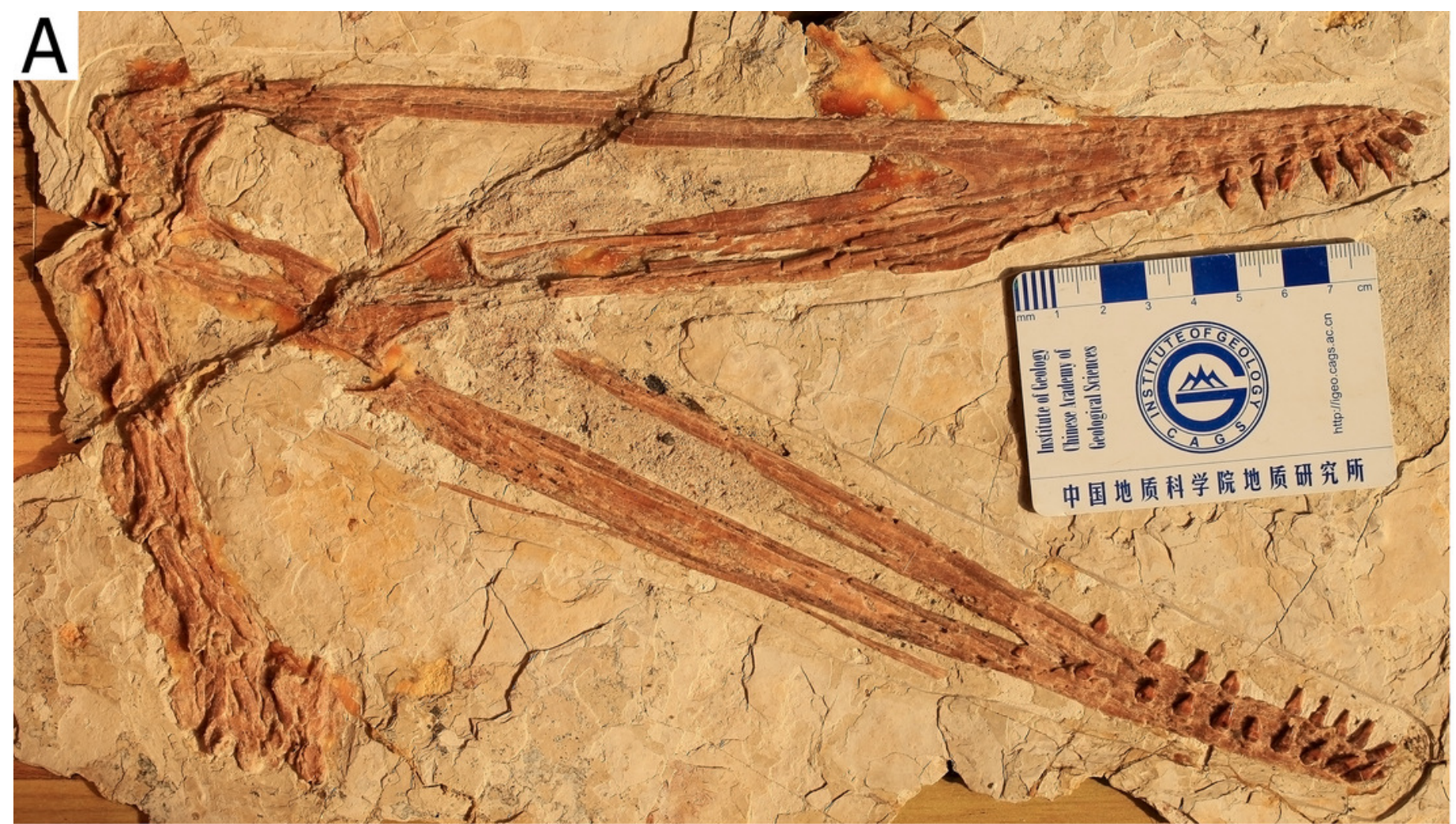

B

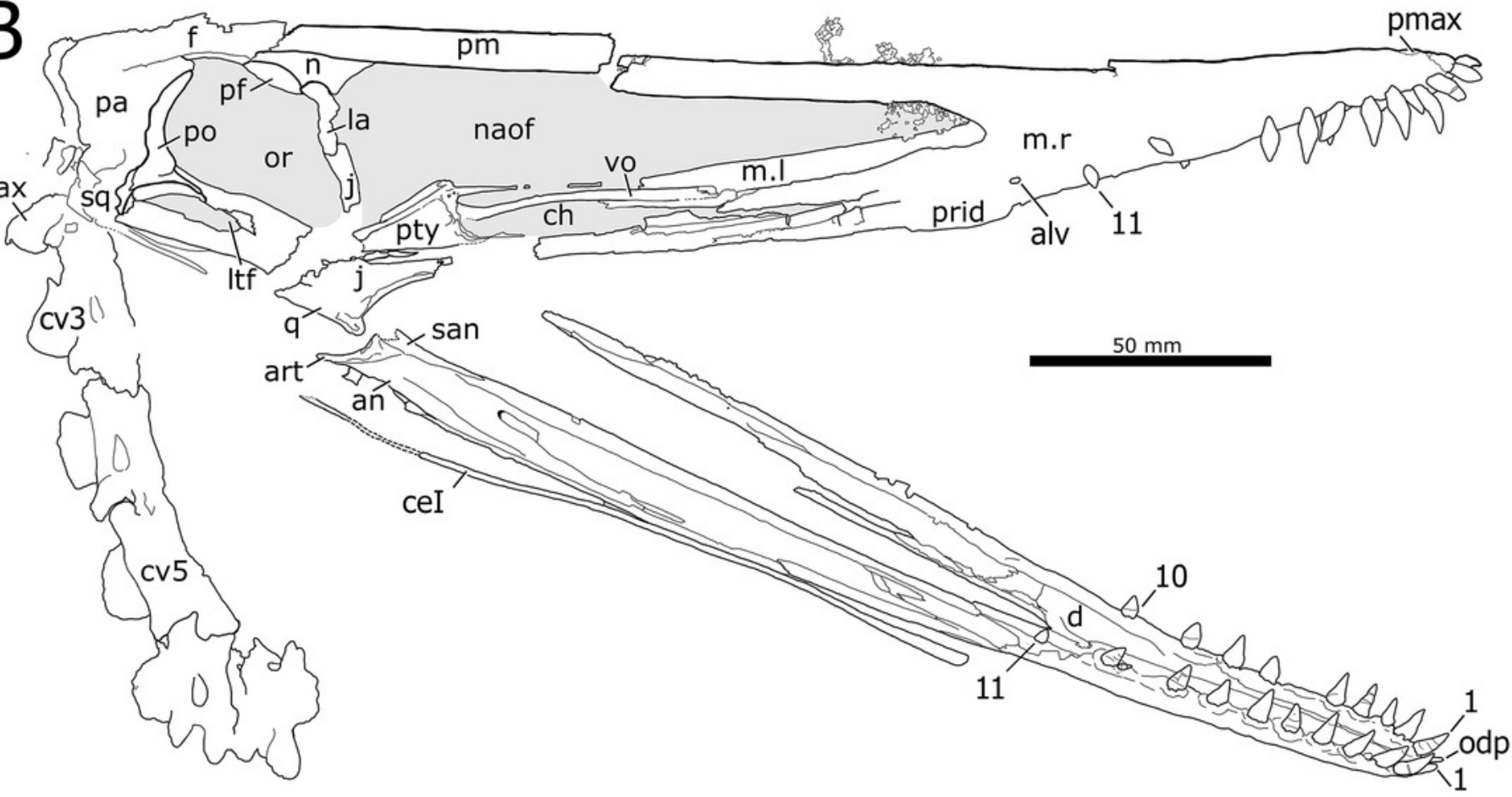


Figure 2

Location of the site where BPMC-0204 was found. 


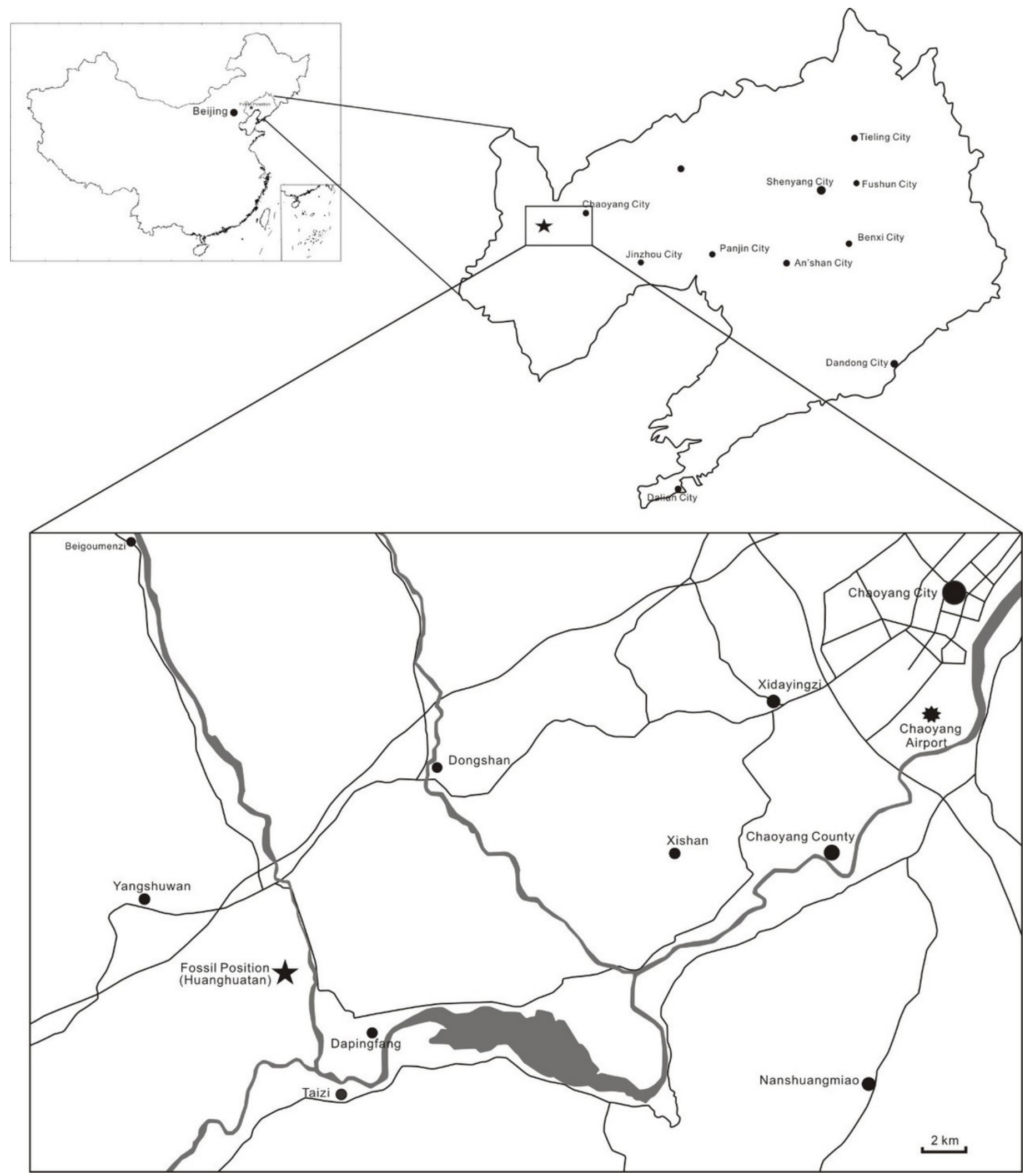




\section{Figure 3}

Nurhachius ignaciobritoi specimens, photographs and line drawings.

(A) LPM 00023, referred specimen (former holotype of "Longchengpterus zhaoi"), skull and mandible in right lateral view; and (B) interpretative line drawing. (C) IVPP V-13288, holotype, skull (mirrored) and mandible in right lateral view; and (D) interpretative line drawing. Scale bars equal $50 \mathrm{~mm}$. Abbreviations: art, articular; ch, choana; d, dentary; f, frontal; ios, interorbital septum; j, jugal; Is, laterosphenoid; m, maxilla; $\mathrm{n}$, nasal; op, opisthotic; or, orbit; pa, parietal; pf, prefrontal; pm, premaxilla; prid, palatal ridge; pty, pterygoid; q, quadrate; san, surangular; sq, squamosal. Photographs by Xuanyu Zhou. Drawings by Rodrigo V. Pêgas.
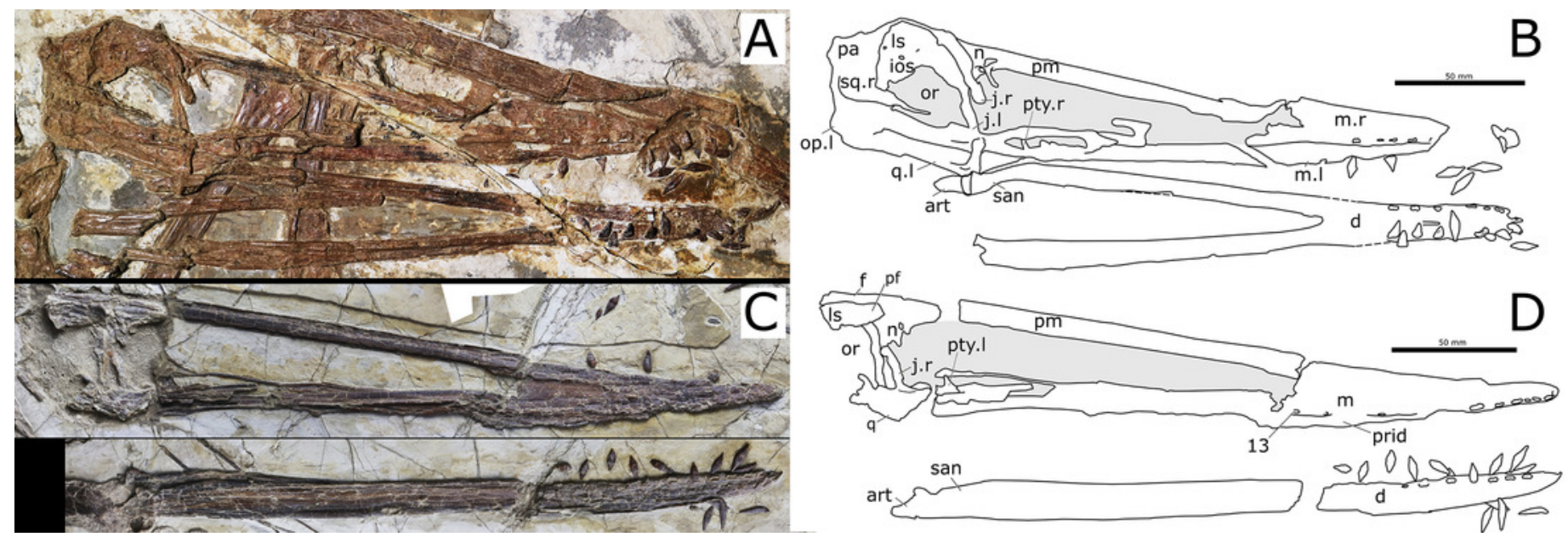


\section{Figure 4}

Close view of the rostral tip of Nurhachius species in right lateral view.

(A) Nurhachius luei sp. nov., holotype and (C) Nurhachius ignaciobritoi, IVPP V-13288,

holotype, mirrored. (B) and (D), respective schematic drawings of (A) and (C), showing the slight dorsal deflection of the palate (notice the positions of the first and second alveoli in both specimens). Numbers indicate tooth positions. Scale bars equal $20 \mathrm{~mm}$. Photos by Xuanyu Zhou. Drawings by Rodrigo V. Pêgas.

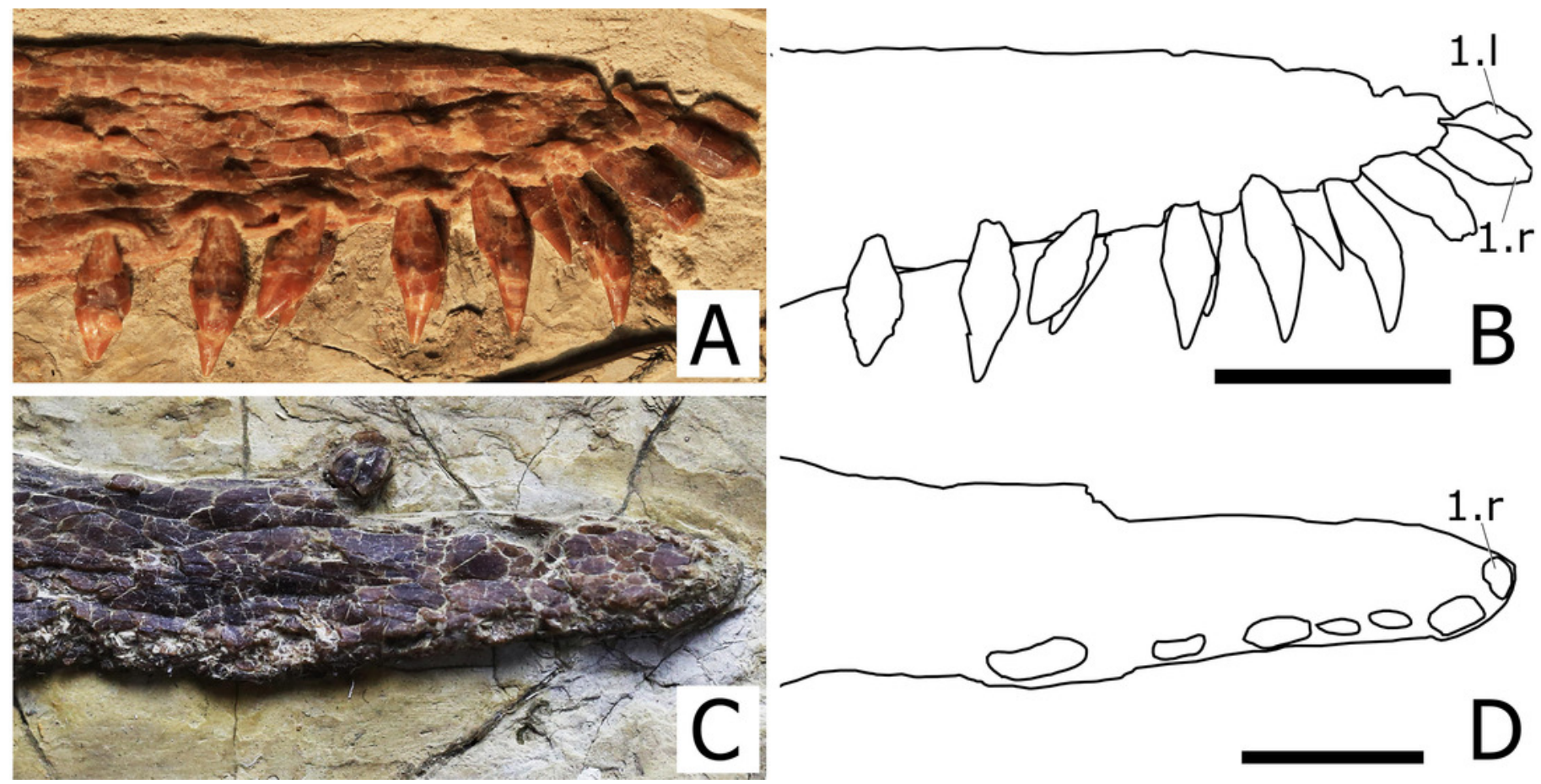




\section{Figure 5}

Close view of the dentary symphysis of Nurhachius species.

(A) Nurhachius luei sp. nov. holotype in dorsolateral view, and (B) line drawing. (C)

Nurhachius ignaciobritoi, LPM 00023, referred specimen, occlusal view, and (D), line drawing. Abbreviations: mg, median groove; odp, odontoid process. Numbers indicate tooth positions.

Red arrows indicate the mesiodistal constriction between crown and root. Photos by Xuanyu Zhou. Drawings by Maria Eduarda Leal and Rodrigo V. Pêgas. 

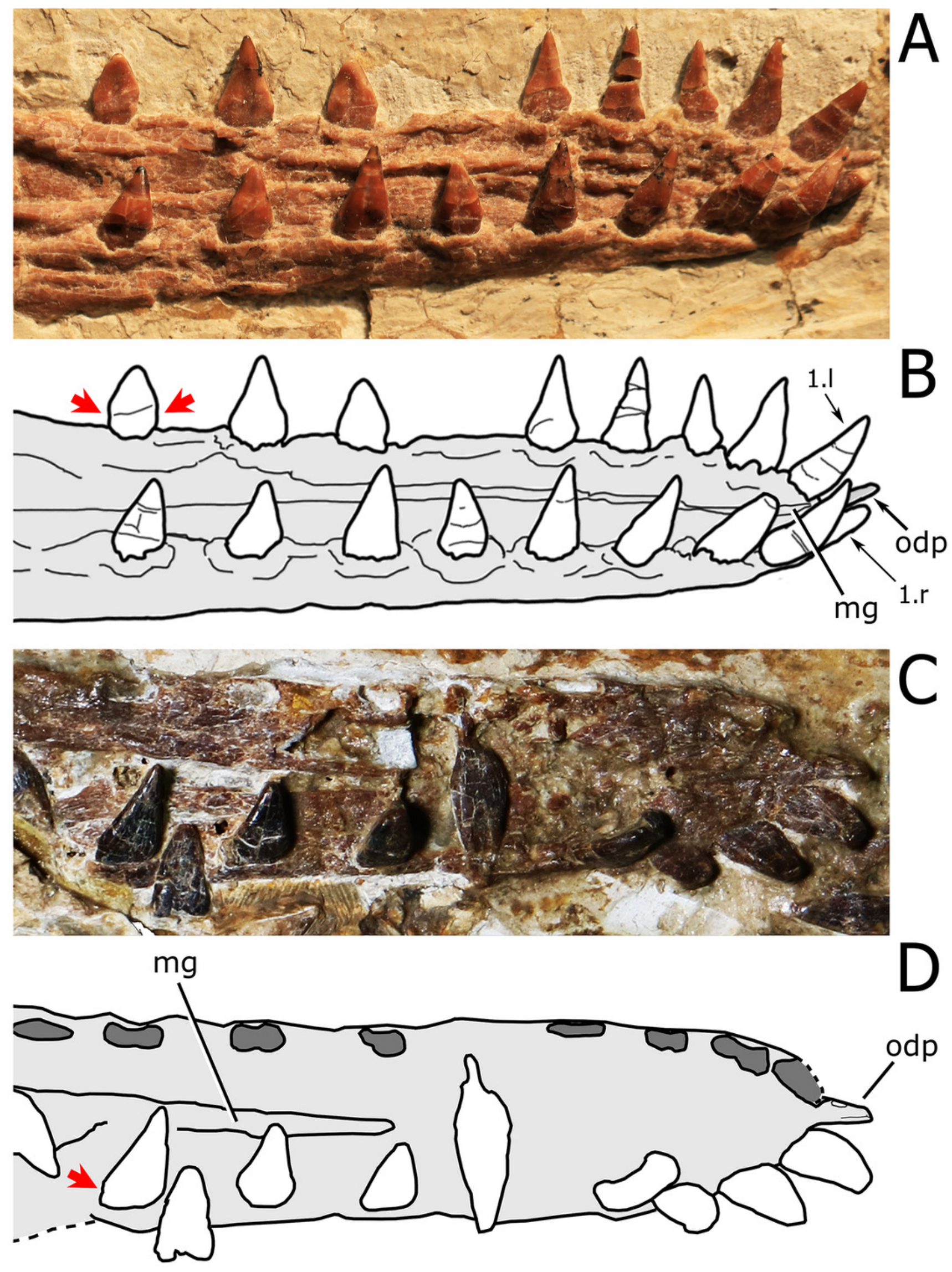
Figure 6

Nurhachius luei sp. nov. phylogenetic relationships.

Strict consensus tree of 51 most parsimonious trees. Tree length is 360 , consistency index

0.642 and retention index 0.864 . The red rectangle indicates the Istiodactylidae and its two closest taxa. 


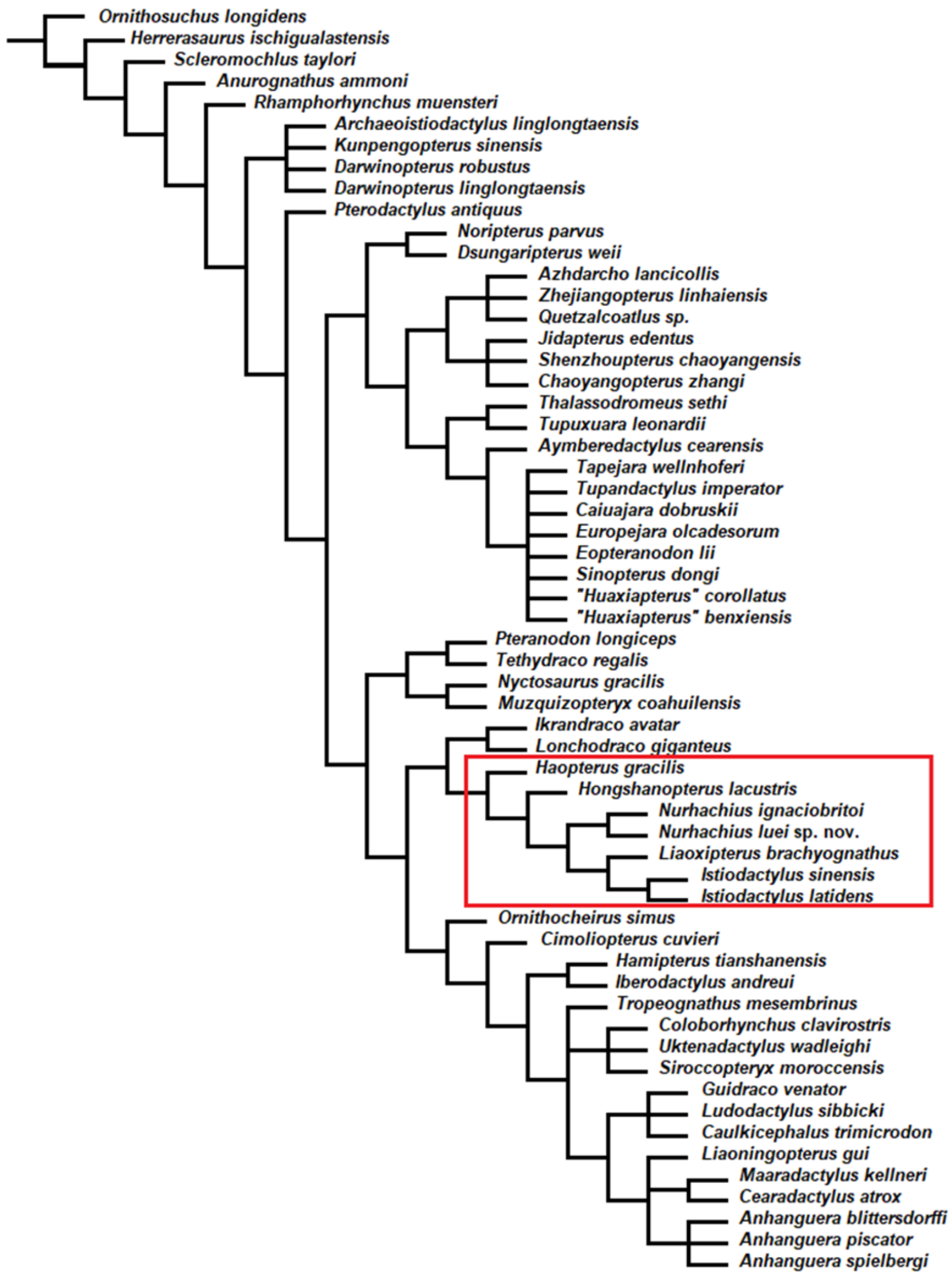




\section{Figure 7}

Close view of the dentition in Nurhachius species.

(A) Nurhachius ignaciobritoi, LPM 00023, referred specimen, isolated tooth in lingual view, and (B) line drawing. (C) Nurhachius luei sp. nov. holotype, ninth left mandibular tooth in lingual view, and (D) line drawing. Red arrows indicate the mesiodistal constrictions between crown and root. Blue arrows indicate the horizontal elevation at the base of the crown (cingulum). Photos by Xuanyu Zhou. Drawings by Rodrigo V. Pêgas.
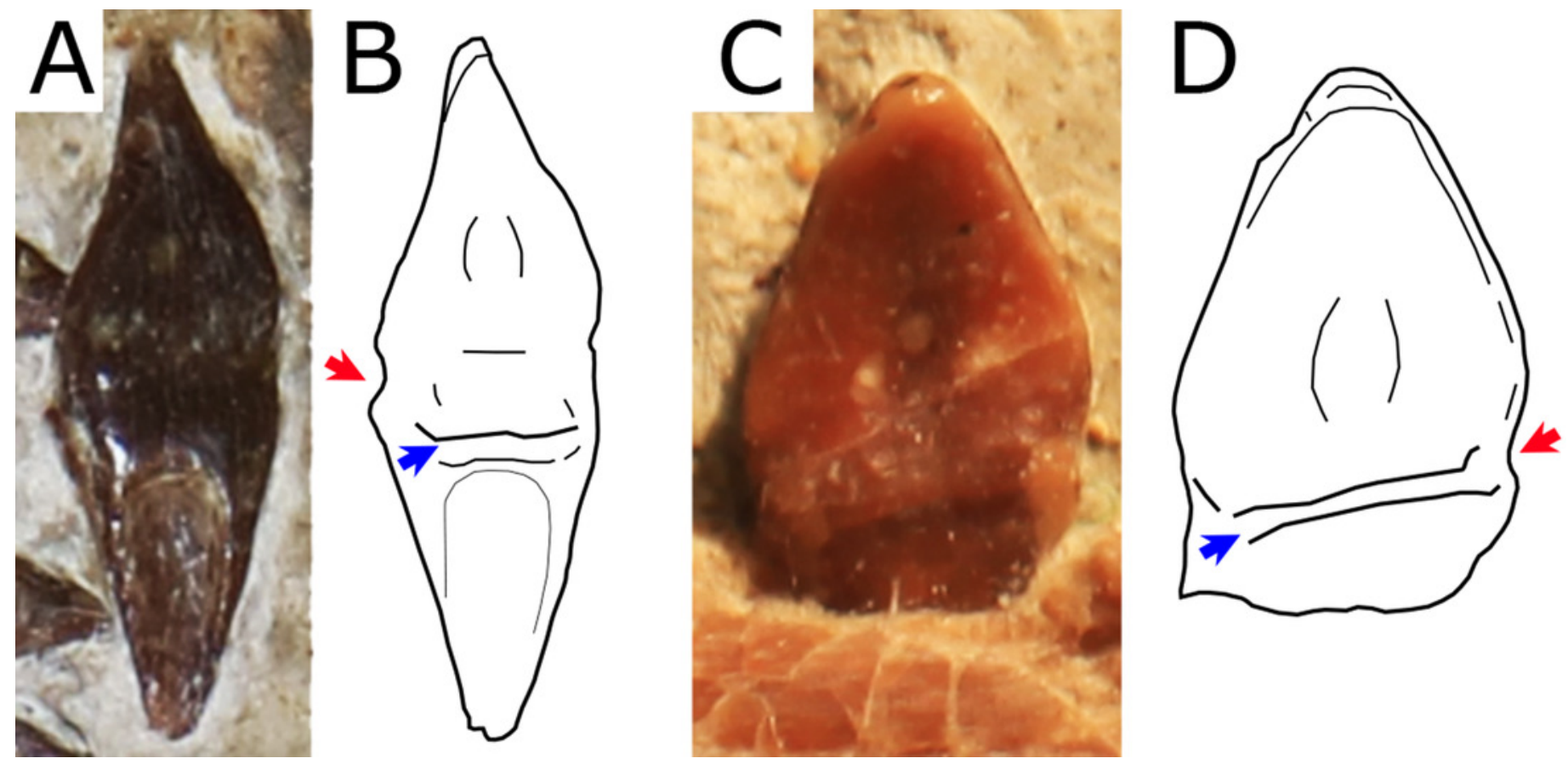


\section{Figure 8}

Other istiodactylids and close taxa.

(A) Liaoxipterus brachyognathus, CAR-0018, holotype, lower jaw in dorsal view. (B) Haopterus gracilis, IVPP V11726, holotype, skull in right lateral view. (C) Hongshanopterus lacustris, IVPP V14582, holotype, skull in ventral view. All scale bars equal $50 \mathrm{~mm}$. (A) and (C) by Xuanyu Zhou; (B) by Shunxing Jiang (courtesy of IVPP).

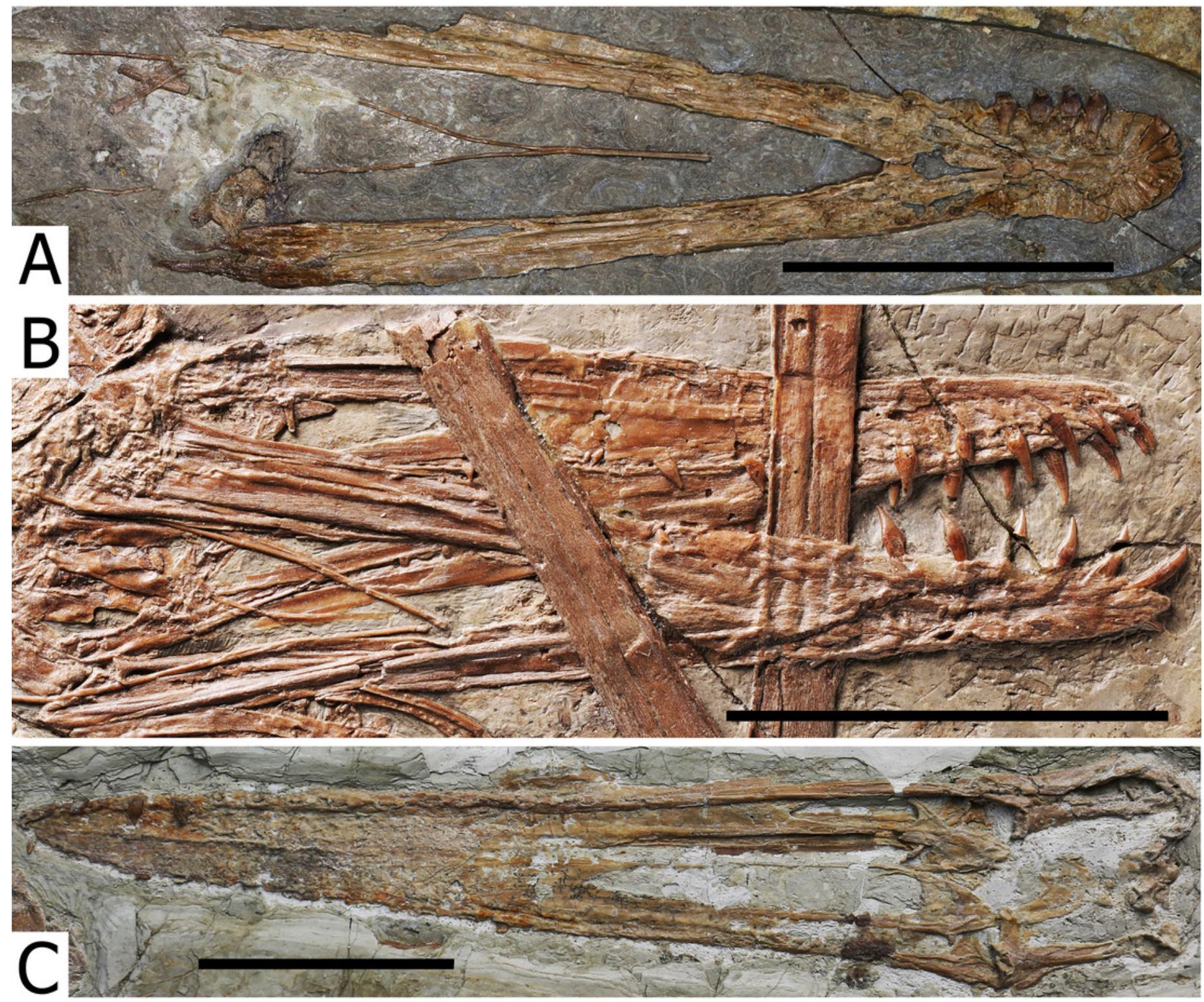

